\title{
HEADPHONE-HEADSET-JETSET DJ Culture, Mobility and Science Fictions of Listening
}

\author{
$\bullet$ Feature Article $\longrightarrow$ \\ SeAN NYE \\ UNIVERSITY OF MINNESOTA
}

\begin{abstract}
This article explores the practice of DJ performance through the use of headphones as opposed to the preferred instruments of analysis: vinyl, turntables and mixers. It focuses on the DJ as a performer who uses headphones on stage, which complicates the traditional construction of "headphone culture" as tending toward exclusively private listening. The experience of the public and private tension of headphones on stage leads to a larger examination of the post-World War II dialectic of mobility, radio communications and recorded music, which is expressed in the constellation "headphone-headset-jetset". In this history, headphones intersect with cultures of command-and-control, aviation and broadcasting. These intersections help to trace the history of the cyborg figure.
\end{abstract}

KEYWORDS: DJ, headphones, club culture, science fiction, radio, cyborg, mobile media

SeAn Nye is a PhD student in the Comparative Studies in Discourse and Society program at the University of Minnesota, Twin Cities. His dissertation project concerns constructions of German identity in popular electronic music between 1968 and 2009. His articles, reviews and translations have appeared in Dancecult: Journal of Electronic Dance Music Culture, New Literary Critique, Cultural Critique, Journal der Jugendkulturen, and Echo: A Music-Centered Journal. Email: <nyex0021@umn.edu>

Dancecult: Journal of Electronic Dance Music Culture 3(1): 64-96

ISSN 1947-5403 @2011 Dancecult http://dj.dancecult.net

DOI 10.12801/1947-5403.2011.03.01.04

dancecult 


\section{INTRODUCTION}

${ }^{6}$ The dj's role is to intensify estrangement, to transmit the currents of the alien. But the dj doesn't know what she wants until she hears it. The Futurist is helpless in the face of fascination. Yesterday this track was unknown, unheard, undreamt. Today you follow it like a sleepwalker.

-Kodwo Eshun (1998: 104)

VINYL RECORDS, MIXERS AND TURNTABLES have long been the preferred instruments through which to explore the DJ as a musical practitioner and performer. In the current moment, however, the questions of what the DJ as performer will become and what DJ tools will be involved are wide open. The discontinuation of the Technics 1200 turntable was announced in 2010 (Tokyo Reporter 2010). We thus find ourselves at a historical and media crossroads, whose moment has in fact been evolving across the last digital decade. Symbolically, the long history of the Technics 1200 (1972-2010) marks the long history of club culture and its close kinship with electronic dance music (EDM) culture from disco to dubstep. What new forms DJing might take, and whether the name "DJ" will be sufficient as a description, are still uncertain. The "DJ" as vinyl mixer, however, already has the aura of the past. A popular example of the new practices of digital DJing is the work of Chris Liebing and Speedy I, who use four laptops and mix with Traktor by Native Instruments. In this sense, the periodization of an era of the DJ within the longer history of disc jockeys is being marked off as I write.

This article is inspired by the openness of the current moment. In particular, the openness of the future in terms of the structures of musical production and reception leads me to reexamine this long period of club culture, roughly 1972-2010, under a larger political matrix. I want to open up the political-social field of DJ club culture toward the future and the past as well as reassess its own era. Two ideas present themselves in establishing this open matrix of the "DJ".

First, I wish to shift the political-aesthetic role of the DJ away from the practice of mixing and toward the question of listening. This move is achieved by diverting attention away from the musical instruments of vinyl, turntables and mixers. My attention is directed rather toward the gadget ${ }^{1}$ so often overlooked in the examination of DJs: the headphone. The question of mixing becomes truly extraordinary on a macro socio-historical level when one considers the enormous shifts in cultures of listening that have occurred over the last fifty years. Mixing, after all, is a demonstration of the mastery of listening in terms of recorded sound, with its associated practices of digging, scratching and sampling. Since the rise of mobile media and the postulating of a global headphone culture ${ }^{2}$ of listening, the modern anthropological figure of the human with headphones has become a ubiquitous image. The examples are numerous. In 1987, Sony released a classic image of the primate with headphones for its Walkman commercial in Japan. The 1997 music video of "Sonic 
Empire", a German chart hit by Members of Mayday, is an important representative of the headphone video. Headphone-style products, from T-shirts to skateboards, number in the thousands. More recently, the popularity of headphones led Dr. Dre to release in 2008 his own line of headphones, Beats by Dr. Dre, which includes celebrity-sponsored headphones by stars such as Lady Gaga and Justin Bieber. This shift in headphone focus from sound to fashion product has, however, caused intense discussion and critique from audiophile communities. $^{3}$

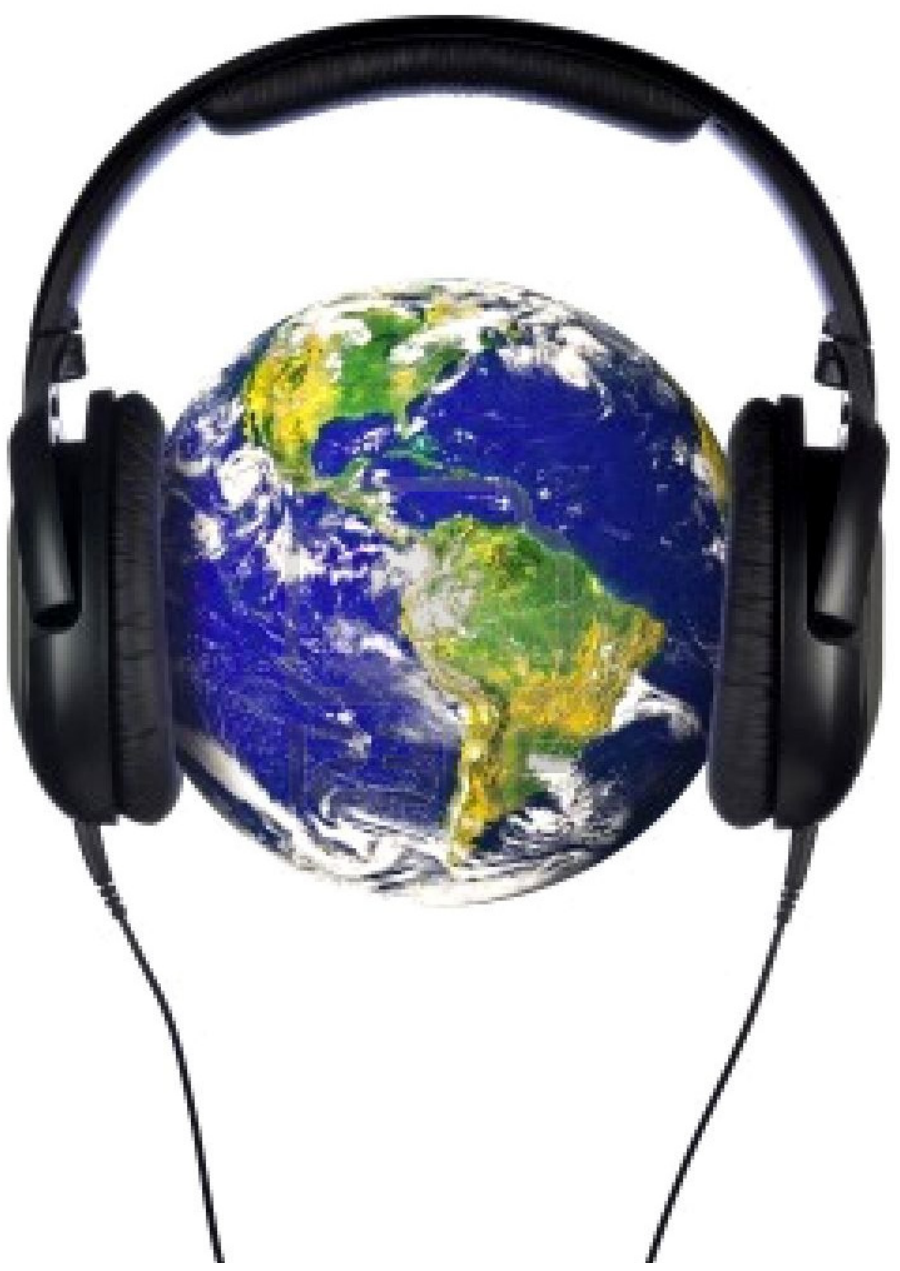

Figure 1: Headphones around the Globe. Source: NASA images.

The image of headphones as a technological extension of hearing symbolizes the electric listening of recorded/transmitted sound and electronic music. Electric listening, as an aesthetic-political concept, expands upon Avital Ronell's analysis of the "electric speech" of telephones. ${ }^{4}$ It is key to this article's analysis of the DJ's social significance, for the club DJ stands as a significant figure in headphone culture: the club DJ is the human with 
headphones on stage. This performative role places the DJ in an important polemical position. It challenges the assumption that "headphone culture" from the 1970s to the present signifies a tendency exclusively toward private listening (Levy 2006: 66-70). Rather, headphones mark a distinctly late modern dialectic of public and private listening, which this article will explore. The dialectic is reflected in the three primary musical uses of headphones to be examined here: music consumption, studio production/sound mixing and DJ performance.

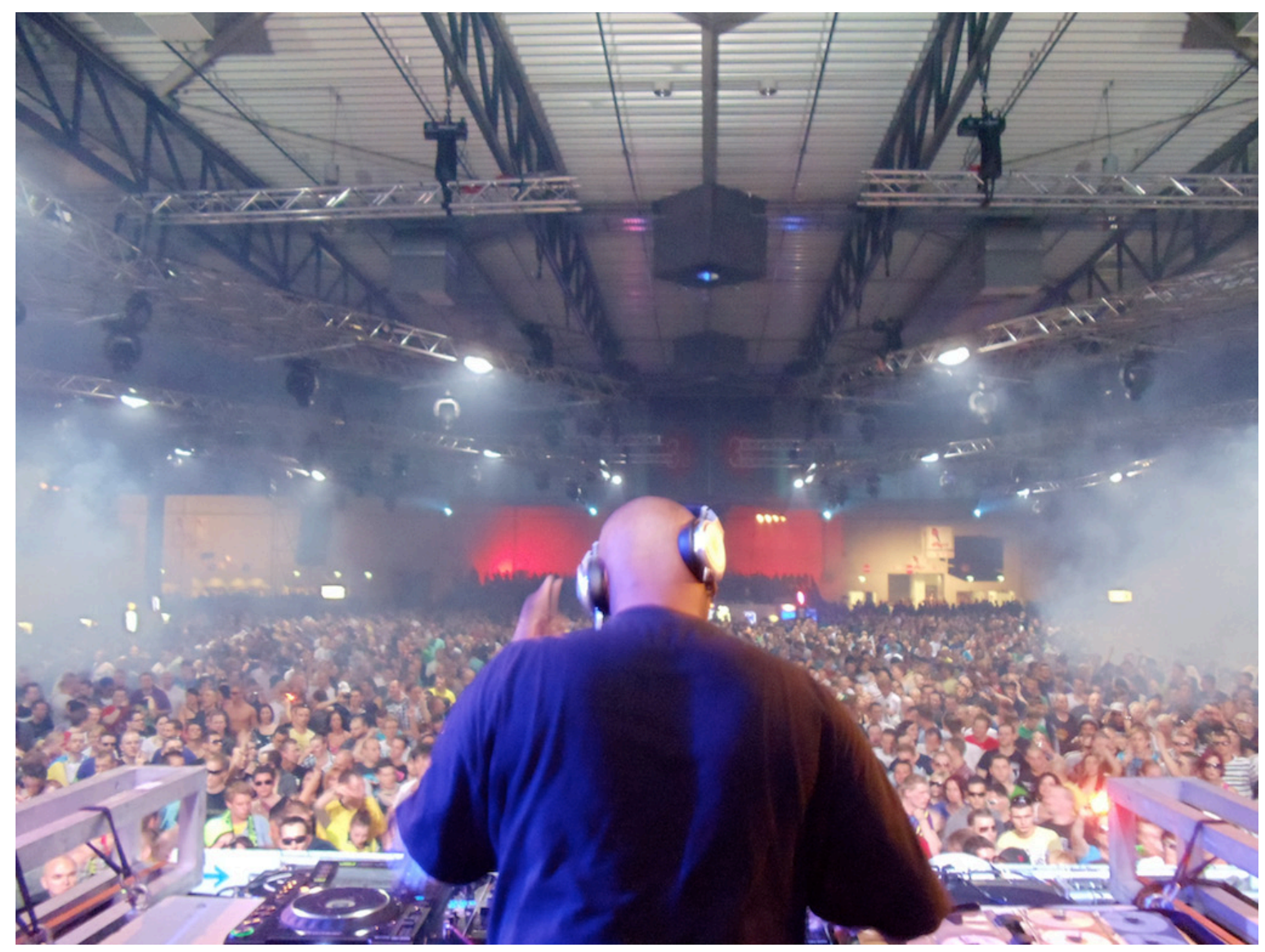

Figure 2: DJ Rush at the "Empire" hall, Mayday, Dortmund 2011. Photo by Sean Nye.

Second, I shift our understanding of headphones themselves to consider the headphone within the larger social history of the headset, by which I mean any combination of headphones/earpieces with microphones. To contextualize the history of EDM culture and Technics 1200s from 1972 to 2010, I enact a double move. First, I place the DJ back "on the air" of broadcast history; second, I place the DJ back "in the air" of aviation history. The political geography of the club DJ with "headphones" is thereby considered alongside the long history of the "headset" broadcast disc jockey (from radio to internet) and the 
"headset" pilot. These figures become a way by which to explore the political geography, technologies and labor history of DJs from the Cold War to the War on Terror. More specifically, the long political arc covers the last fifty years from the Cold War politics of the space age and radioactivity to the current dialectics of internet hyperconnectivity and earbud culture in the War on Terror. Broadcasting is important to questions of geography and the demarcation of territory while marking the prehistory of the DJ's facelessness. After all, what political "body" is behind the voices on the airwaves? Finally, EDM club culture is considered within the long history of jetset culture, which has consequences for both club travel and the ideological association of DJs with mobility and modernity.

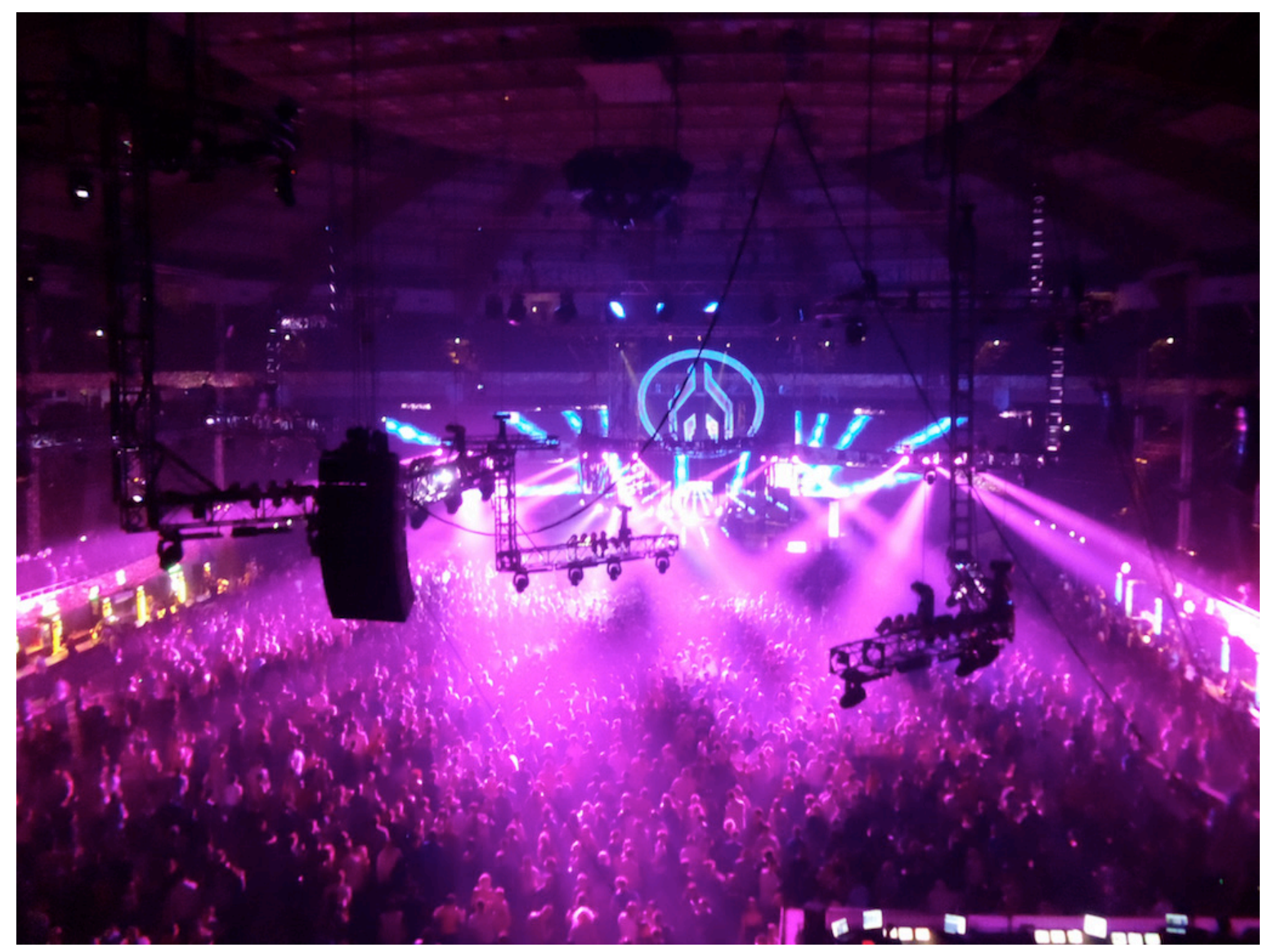

Figure 3: Germany's oldest mega-rave, the Mayday, takes place annually at the WestfallenHALLEN IN DORTMUND. IT BOASTS A MASSIVE JET-ROCKET INSIGNIA, ITS LOGO SINCE 1992. THE INSIGNIA

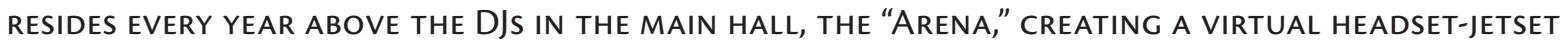
ALTAR. THE 20-YEAR ANNIVERSARY OCCURRED ON 1 MAY 2011, WHICH SAW 27,000 VISITORS ATTEND AND THE JET-ROCKET LOGO AGAIN PROMINENTLY ON DISPLAY.

Photo by Sean Nye (During DJ Performance by SANDer VAN Doorn). 
To highlight issues of listening, the following article operates within a matrix of artistic works, primarily concerning science fiction, that demonstrate the explosive shifts in DJ and headphone understanding. It is a mix of travel literature, cultural theory and media constellations. As we shall see, the politics of EDM's liberatory pleasure, while inspiring, are also humbled before the political and economic challenges of headset culture. My concern is not a detailed media analysis of the models, designs and technological developments of headphones, though such issues are important and will be addressed on occasion. Rather, the concern is to highlight the political and social interpretations and cultural iconography of headphones. While high-speed travel marks our times, regional distinctions and local organizations of headphone culture remain strongly present.

The historical constellation of "headphone-headset-jetset" thus begins in medias res with a journey from the Californian coast to a symbolic city of EDM club culture: Detroit. Occurring in the pivotal year of 2001, this trip explores a moment in the post-Cold War height of EDM popular culture and the star DJ system, immediately prior to the dialectic of terrorism and internet communications marking the 2000s. Based on this trip, I investigate the theoretical debates about headphone culture and the privacy and poverty of listening which have existed since the 1970s. By questioning such debates, I am led further back in time to the beginnings of the headphone, headset and jetset constellations surrounding the Cold War conflicts at the dawn of club culture. Using Donna Haraway's figure of the cyborg, I make a dialectical case study of two borders of the "West", West Germany and California. They are examined under the rubric of Laurence A. Rickels' analysis of these regions as "Coasts", ${ }^{5}$ which prove to be key sites of postwar techno culture and science fiction. This historical retreat to the 1960s dawn of club and jetset culture leads me to return, in the final section, to an assessment of DJ headphone performance in my experience in Detroit and the late history of star DJs.

\section{Detrolt 2001: EDM ON THE CUSP}

THE WEEKEND of 25-26 August 2001 was a symbolic moment for EDM culture, and a significant and tragic weekend in the history of music from Detroit. Here is the background: a few months prior, a friend named Gabe came to me with a proposal. Madonna was on her Drowned World Tour, promoting her EDM-inflected albums Ray of Light and Music, produced by European trance stars William Orbit and Mirwais Ahmadzaï. Gabe went online the moment tickets went on sale. Within hours, the only good tickets remaining were for Madonna's concert on 26 August in her hometown of Detroit, each costing \$120. Gabe offered me his second ticket for free if I paid for my flight from San Francisco to Detroit, a truly generous offer for someone who was a techno enthusiast and who had never been to Detroit.

We flew with American Airlines on 24 August. On the flight, I put on the headphones provided by the airline and listened to the radio and inflight programs. I also listened to music on my Sony Discman with my personal headphones. Arriving in the evening, we 
travelled the following day, as dystopian "trauma tourists" (Pope 2011: 41-2), around the post-industrial emptiness of downtown Detroit. While driving, Gabe would wear a headset when he needed to talk on his cell phone. We also had a mix of Madonna tracks burned onto a blank CD. After walking around the Renaissance Center and discussing Lee Iacocca and the late history of the Detroit auto industry, we headed across the Detroit River and over to Windsor, Canada.

This was the occasion for an extraordinary stroke of luck. I had assumed no major EDM events were happening in Detroit, since the Detroit Electronic Music Festival (DEMF) had already taken place in May. Seeing Madonna seemed more than enough. But as we travelled through downtown Windsor in the mild afternoon, I spied some raveresque kids sporting visors and kick-pants. I immediately asked Gabe to stop the car and asked what they were up to. They responded in disbelief, "You don't know? It's Life Fest: Windsor's answer to DEMF. Richie Hawtin, Juan Atkins, Kevin Saunderson, Carl Craig, Gene Farris, and tons of other DJs are playing."

I was in shock, and we changed plans accordingly. Suddenly, within hours of arriving in Detroit and with no plan, I was on the Windsor Plaza waterfront from roughly 3:00 PM until 2:00 AM, participating in one of the most significant regional EDM events of 2001. With around 4,000 people in attendance, the party was quite intimate. However, with its location in Windsor, the excessive focus on Hawtin over the African-American DJs was evident (Keene 2001). I talked to some drugged-out raver kids and bedroom-DJ enthusiasts as they celebrated each new DJ on stage. DJ followed DJ; the long hours tested the endurance of the techno tourists, and the sun went down across the Detroit River with the cityscape of Detroit in perfect view. As the sounds and sights of dystopia (Pope 2011), both the techno music and the cityscape evoked an experience that resisted traditional jetset tourism. The experience was similar to how Cybotron's classic track, Techno City, critiques the voice of the tour guide in experiencing Detroit: "Ooh, Techno City, hope you enjoy your stay; Welcome to Techno City, you will never want to go away".

The various DJs were on a raised stage and at a distance from the audience. The main action the audience could see was their placing of headphones in different positions. Indeed, the variety of headphone poses that DJs can make is impressive, especially if they are performing on a raised stage. After the sun had gone down, the backlit lasers caused a silhouette effect, with only the outlines of headphone-skulls present. The experience is common to many club-goers: at EDM-events across the world, the headphone-skull is the primary object seen on stage.

The next morning, Gabe and I headed back across the border. The American authorities knew about Life Fest, so our car was searched for drugs, but we were allowed back into the USA. We proceeded to the vast suburbs of Detroit's immense sprawl late Sunday afternoon, arriving at the promised place: the Palace of Auburn Hills. There we would see the next icon from Detroit: Madonna.

Life Fest put in perspective the economic differences between EDM events and pop 
events: \$30 for multiple DJs' performances of “recorded" music between 3:00 PM-2:00 AM versus $\$ 120$ + for Madonna's one-and-a-half hour "live" show. Her first appearance on stage alone, however, was worth the price of admission. The moment she emerged, every member of the 20,000+ audience of primarily women and gay men let out her/his Madonna diva in an eruption of hands in the air and ear-piercing screams. The entire stadium underwent a transformation into a micro-climate of diva steam-a hothouse of house-inflected pop music.

Soon Madonna was singing "Ray of Light". The performance included images from her music video, with its distinctive use of time-lapse photography as a marker of highpaced modern life and world travel. In the video, Madonna eventually arrives "home" on a disco dance floor complete with vinyl turntable. This time-lapse effect borrowed from the aesthetics of the distinctly jetset film that, to the tune of Philip Glass' minimalist soundtrack, pioneered such effects with aerial shots: Koyaanisqatsi (1982). "Faster than the speeding light she's flying; trying to remember where it all began”. Paradoxically, Madonna's jetset song was introduced with her only acknowledgement to her hometown: "Give it up Detroit!"

Madonna concluded with "Music", mixing in samples from Kraftwerk's "Trans Europe Express". Whereas great DJ icons had performed the day before, here was the most iconic pop diva of late modernity making her final request: "Hey Mr. DJ, put a record on". Dancers, all wearing headphones, accompanied her on stage. However, these "headphones" were "unreal" in so far as they were specifically designed as stage props. With no actual brand, the props represented the headphone as idea and fetish. Madonna sang atop a turning wheel representing vinyl; the headphones were, however, the primary sign that DJ culture was on stage. The dancers made eroticized poses with their headphones, auto-erotic to the extent that the headphones made them appear as though they were performing in private. "Music" was metaphorically received into the headphones of the dancers, overwhelming their ears and bodies. Here was hearing - on the brink. On stage, the headphones were many things: modern fashion fetish; signifier of the consumer as queen (not king); and the link of club, disco and pop lives in the concert stadium. This was a symbolic moment in DJ culture at its height of pop myth in fin de millenium postmodernity, embraced by Madonna at the same time that the rave massives were achieving their height of popular success.

Gabe and I finished the concert and made our way back to the hotel after midnight. We needed to catch a 7:00 AM flight on Monday, so we collapsed in the hotel near the airport, listening to some soothing music on our Discmans. Finally, early the next morning, we caught up on the news. In the airport, I put on my simple on-ear Sony headphones to listen to the radio news. It was then that we learned of the tragedy that had clouded the weekend. Detroit's greatest new musical talent, Aaliyah, had died aged 22 on that Saturday, roughly at the same time as Life Fest. She had died in a plane crash while returning from a music video shoot in the Bahamas. Her self-named album had taken the 2001 airwaves by storm, with the Timbaland-produced track "Try Again" described as providing "a missing link between hip-hop and electronica” (Cinquemani 2001). 
As we landed in San Francisco on the morning of 27 August 2001, we were thinking about the dangers of flying with reference to Aaliyah. Little did we know that this would be our last trip of relatively carefree jet travel. 11 September 2001 was a couple of weeks away. The decade of war and security threats to follow would see ramifications for the transAtlantic jetset communication between DJ cultures. ${ }^{6}$ Yet, as the world worried about the "openness" of the West in the face of terrorism in 2001, the dialectical side of increased mobility and networking was very shortly to be announced in a ground-breaking event a few weeks later. On 23 October 2001, Steve Jobs introduced a portable gadget called the "iPod". The video presentation concludes with Jobs' remark: "This amazing little device holds 1000 songs, and it goes right in my pocket”. A week later, across the Atlantic, a key piece of software for musicians and DJs, Ableton Live, was also introduced. The new media of the decade for both headphones and DJ culture were spreading rapidly in fall 2001.

\section{Thought TRIP: Privacy AND Mobility}

THIS TALE of a "headphone-headset-jetset" weekend represents musical currents on the cusp of the 21 st century and at the height of EDM's popular success. The deluge of music and information poses important implications for DJ culture as a historical practice. The currents of three great traditions of club culture all intersected in this Detroit weekend-not just EDM but also pop-disco and hip-hop/R\&B. Yet the presence of headphones throughout the weekend demonstrated the complexity of headphone culture. Indeed, whatever equipment might be present on stage, in the car or in the airplane-from turntables to radios to Discmans to laptops to cellphones-what remained constant throughout were the headphones, in different sizes and forms, and put to various uses.

These headphone uses lead me to consider the dialectic that has, in fact, existed between DJ culture and headphone culture since the 1920s, when gramophones and the radio first achieved mass-market success (Brewster and Broughton 2000: 22-4). The 1970s marked some important technological changes; the production of the Technics 1200s, as index of club culture, took place across a broad arc in which both DJ and headphone culture were transformed by new media and practices of mobility. The introduction of the iPod and Ableton Live, mentioned in the 2001 trip, were late manifestations. The following dates should be considered as part of the long media arc of DJ club culture:

1972 Technics 1200

1976 VHS tapes

1979 Walkman

1982 Compact Disc

1984 Discman and Apple Macintosh

1993 MP3

1994 Pioneer CDJ 500

1995 DVD

2000 Traktor

2001 iPod / Ableton Live

2010 Discontinuation of Technics 1200 and Walkman. ${ }^{7}$ 
This post-1960s dialectic of DJ and headphone culture was heightened by the coining of the latter phrase in the 1970s to mean a very specific practice: that of, if not isolated listening, then individual or private listening. The implications of this overemphasis in the age of mobile media are difficult to overestimate. The theorization of "headphone culture" will remain limited if it only constructs the headphone listener as private and solitary and traces its understanding only back to the late 1970s. This focus has been popularly developed with Walkmans and iPods in mind. In fact, marketing campaigns by Sony, and later Apple (Gunn and Hall 2008: 147-8) that portray the consumer as an autonomous individual seemed to extend their success even as far as the academy's reception of the headphone. The theoretical critiques in which headphones are imagined as the privatized poverty of listening can be traced into the present. It has been paralleled by the perceived miniaturization of headphone culture from the 1970 s to the present, with the quantitative storage of sound in inverse proportion to miniaturization: from the circumaural headphones of stereos, to the on-ear headphones of the Walkman, to the in-ear headphones (earbuds) of iPods. In-ear headphones have themselves been refined into in-ear-monitors (IEMs), with ear canal seals that allow for optimal sound isolation and acoustic experience. To be sure, this mobile miniaturization has been paralleled by the continual refinement of audiophile circumaural headphones.

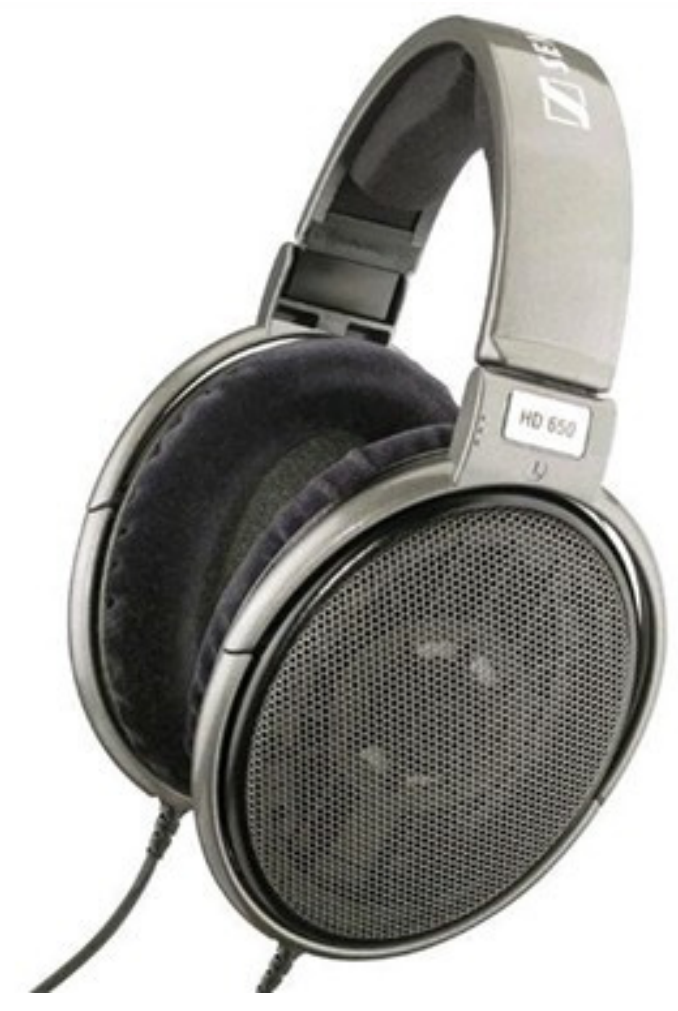

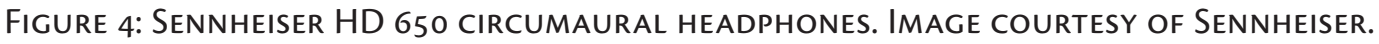




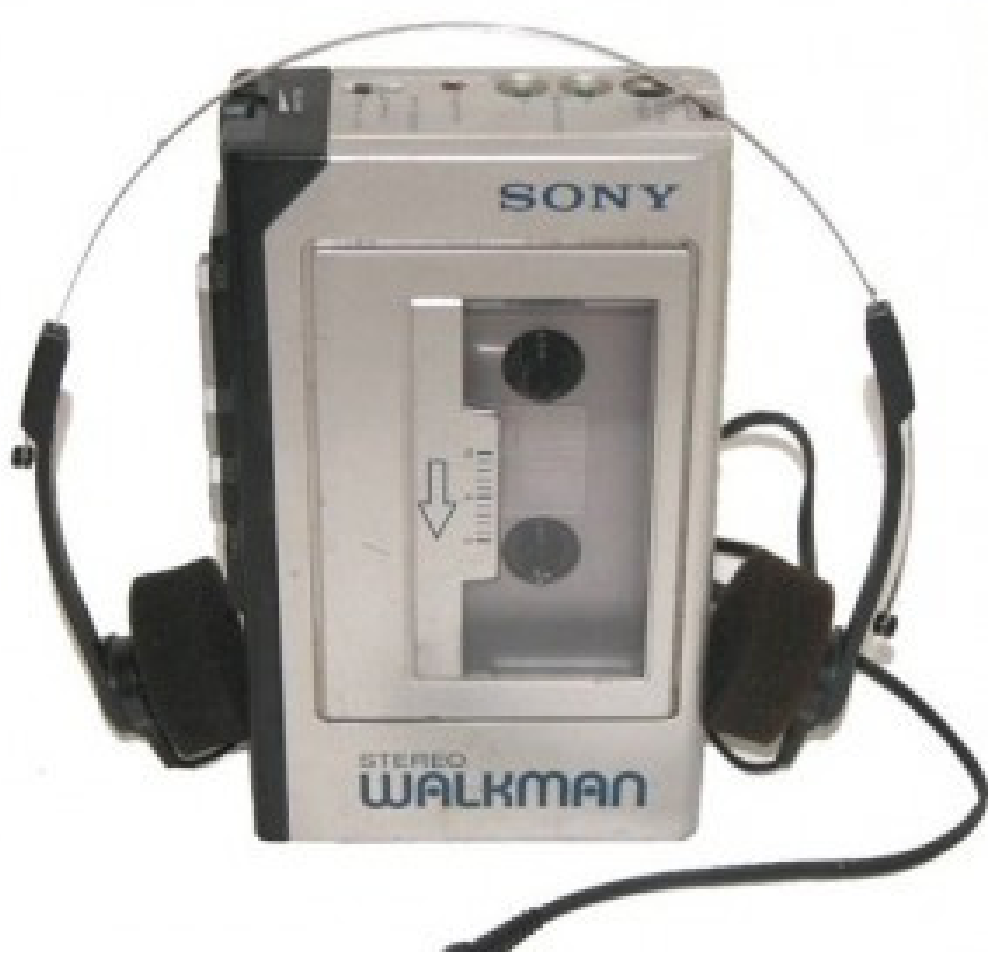

FiguRE 5: WALKMAN AND ON-EAR HEADPHONES. IMAGE COURTESY OF TECHNOLOGY UPDATES.

It should be pointed out that these interpretations of headphone privatization bear a longer history. They can be traced as far back as the 1880s. In the most reflective and extended discussion of headphones in recent academic literature, Jonathan Sterne (2003: 154-77) analyzes how images of headphones in advertisements and other print media between the 1880s and 1920s formed the initial basis for constructing private acoustic space. He argues: "The auditory field produced through technicized listening (whether by convention or prosthesis) becomes a kind of personal space. The individual with headphones is perhaps the most obvious example of the phenomenon" (2003: 158). Sterne makes clear the consequences for capitalism: "Put simply, acoustic space modeled on the form of private property allows for the commodification of sound" (2003: 162).

This representation of commodification was heightened in the 1970 s with the popularization of audiocassettes and mobile media. In the early 1970s, while acknowledging the importance of stadium sound systems, R. Murray Schafer succinctly argued: "Headphone listening is isolating the listener in a private acoustic space. Messages on earphones are always private property" (Schafer 1973: 35). Following the introduction of the Walkman, and in a more conservative context, Allan Bloom used the final line of his chapter "Music" from The Closing of the American Mind to sum up the commodified nature of the device: "but as long as [youths] have the Walkman on, they cannot hear what the great tradition has to say. And, after its prolonged use, when they take it off, they find they are deaf" (1987:81). 


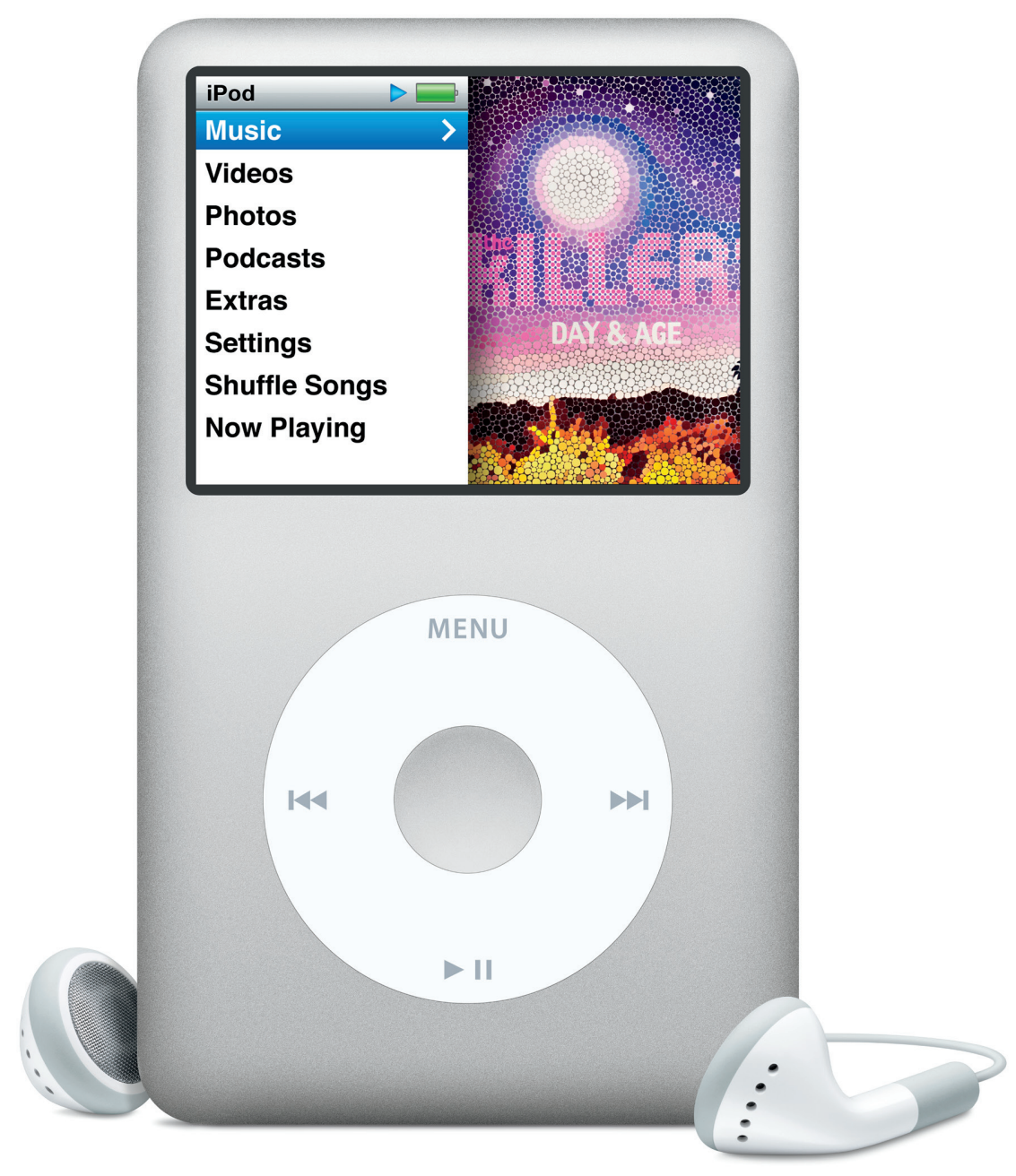

FIGURE 6: IPOD AND EARBUDS. IMAGE COURTESY OF APPLE.

He also accuses youth of indulging in a media spectacle that is a "nonstop, commercially prepackaged masturbational fantasy" (1987: 75). This form of accusation, which amounts to a charge of public masturbation, has been shown by Gunn and Hall to have continued with connections to blindness and what I will term the "earbud culture" of the iPod: "Related to this caricature of the iPod user is a warning analogous to going blind, but a valid one nonetheless: frequent and prolonged use of the iPod causes hearing loss" (2008: 136).

Thus, headphones signify both "private" masturbatory space and the closing off of intersubjective communication when worn in public. The comparison to blindness is significant. I would argue that, in the context of constructions of postmodernism, the debates on mediation and headphones can be seen as the acoustic counterpart of reflector sunglasses and Wayfarers, which saw a rebirth in popularity at the same time as the rise of Walkman culture. Sunglasses, like headphones, cause anxieties about intersubjective 
communication. Sunglasses represent the mediation of the gaze between two subjects. In fact, it cuts off the interlocutor's ability to read the eyes. Fredric Jameson discusses this issue in reference to the Bonaventure Hotel as symbol of postmodernity:

Now one would want rather to stress the way in which the glass skin [of the Bonaventure] repels the city outside, a repulsion for which we have analogies in those reflector sunglasses which make it impossible for your interlocutor to see your own eyes and thereby achieve a certain aggressivity toward and power over the Other (Jameson 1991: 42).

The reflector glasses are the sign of the eyes gone inward and egotistical at the same time as they achieve domination over what one is looking at.

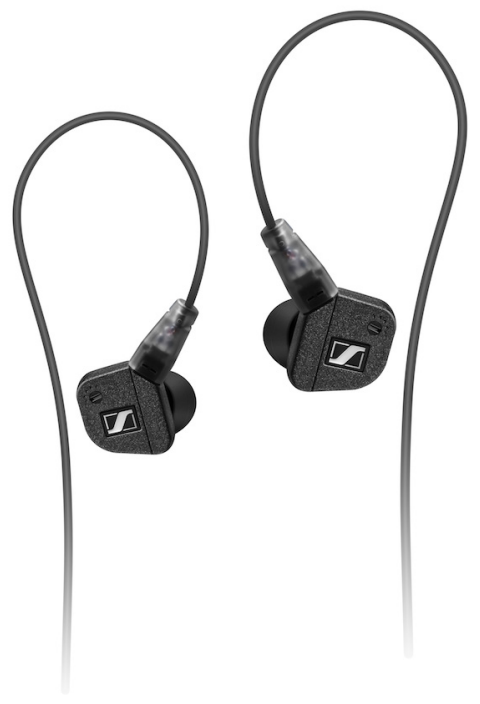

Figure 7: SenNHEISER IE-8 IN-EAR-MONITORS. IMAGE COURTESY OF SeNNHEISER.

The chief postmodern novel to notice the role of sunglasses in the context of recording media, MTV and electric speech was Bret Easton Ellis's 1985 debut, Less Than Zero. In this novel of 195 pages, sunglasses are mentioned specifically 49 times. In fact, sunglasses are first mentioned in a musical context. The protagonist-narrator, Clay, stares at his bedroom poster of Elvis Costello, whose song "Less Than Zero" gave the book its title:

Elvis looks past me, with this wry, ironic smile on his lips, staring out the window. The word "Trust" hovering over his head, and his sunglasses, one lens red, the other blue, pushed down past the ridge of his nose so that you can see his eyes, which are slightly off center (Ellis 2010: 3).

Less Than Zero proves to be saturated with musical references to primarily New Wave bands, radio-stereo playlists and MTV to the point where it could itself be considered a key literary 
work of electric listening. The sunglasses, as visual equivalents to headphones, reflect the inundation with media, fame and pleasure that is the content of the vapid conversations in the book, often performed through the electric speech of telephones. This inundation comes to literal, sexual climax towards the middle of the book when Clay meets a girl with whom he has sex. However, they do not touch each other. Rather, they stare at each other while each masturbates using Bain de Soleil suntan lotion as lube and while Clay wears Wayfarer sunglasses:

I take the sunglasses off and she tells me to put them back on and I put them back on and it stings when I come and then I guess she comes too. Bowie's on the stereo and she gets up, flushed, and turns the stereo off and turns on MTV. I lie there naked, sunglasses still on, and she hands me a box of Kleenex (Ellis 2010: 110-1).

Communication in the age of electronic media is here a study either in total self-absorption or passive-aggressivity. Like sunglasses, headphones indicate that you are not interested in a conversation and make it impossible for a potential interlocutor to know what you are hearing. ${ }^{8}$ The dialectic of sunglasses and headphones, as mediation of sight and sound, later achieved total synthesis in the extraordinary science fiction of the iSpec. A sci-fi advertisement to earbud culture, the 2003 commercial by Tron: Legacy director Joseph Kosinski imagines what the future iPod will become. His sci-fi gadget, the iSpec, is a fusion of iPod and 3-D/virtual reality glasses (the logical update of Walkman and Wayfarers), along with hand-motion sensors as an update to the joystick. With the iSpec, one can select any world, film or musical experience one likes. The result: the iSpec envisions the total absorption into a solipsistic techno-world of the 21 st century.

\section{DISC JOCKEYS AND THE COLD WAR}

AMIDST THE PERCEIVED HISTORY of the tendency toward the private, however, the disc jockey announces itself as a strange figure. In this context, Sarah Thornton's 1995 book, Club Cultures, offers an outstanding analysis of EDM cultures and recording technologies. She argues dialectically against the singular tendency of individuation with reference to recorded music. Thornton states: "Recorded music is as much a feature of public houses, shops, factories, lifts, restaurants and karaoke bars as it is an attribute of the private home" (1995: 34). Tracing the battles between the recording industry and musicians' unions, Thornton uncovers recorded music's "progressive colonization of public spaces" (1995: 35). Headphone debates can thus be seen as a subset of larger debates regarding listening to recorded music, whose dominance of public space by the 1960 s proves to be the precondition for debates on total headphone isolation. The miniaturization of mobile media is a subset of debates on global integration and mobility with reference to headset and jetset culture, as was exemplified in my Detroit trip.

Whereas the headphones emphasize electric listening, headset command-and-control emphasizes the electronic communication of both electric listening and electric speech. Ships, bases, airports and other command-and-control centers during the world wars 
rapidly became famous loci of headset communication. Before the DJ became the stage star, the club DJ was located as standard in a specially enclosed "DJ booth" that invoked this headset heritage of radio and command-and-control centers. Off to the side and away from the public's attention, the DJ booth recalls the sound mixer who is usually located behind the audience. ${ }^{9}$ This aesthetic heritage of the DJ booth was most recently exemplified in the cyborg performance by Daft Punk in Tron: Legacy (Kosinski 2010). The duo performs their "soundtrack" in an exclusive club atop the main tower of Tron City as techno-Disneyland.

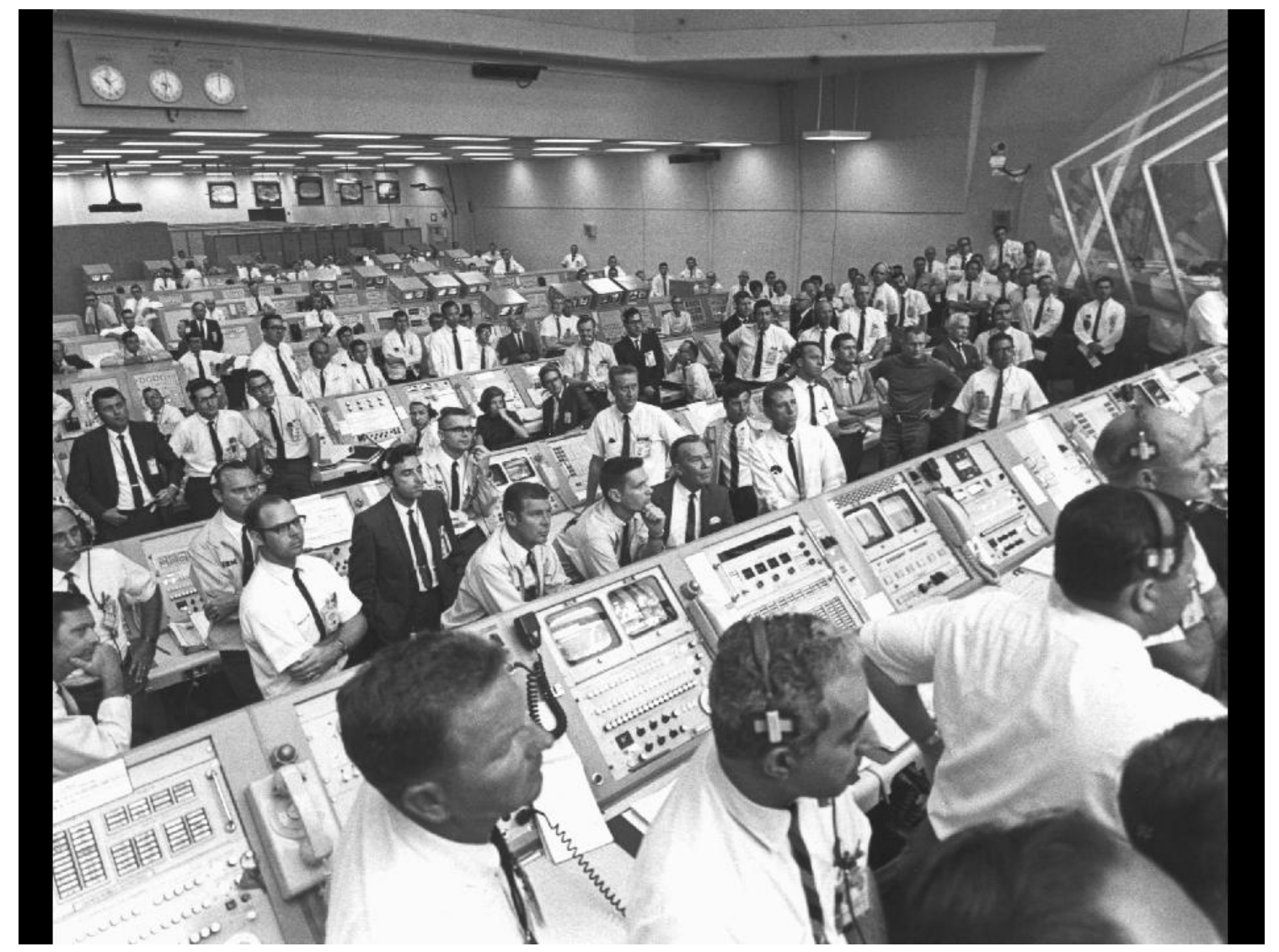

Figure 8: NASA Control Room, Apollo 11 mission, Johnson Space Center, Houston 1969. SOURCE: NASA IMAGES.

In this sense, the framing of headphone culture as only tending in the direction of the private does not examine the constant dialectical exposition of the private through electric speech-whether through espionage, market research, the posting of playlists or radio DJ announcements between recorded songs. Desires for headphone isolation might thus be seen as the desperate search for private moments within headset exposition, rather than the excess of isolated autonomy.

Furthermore, in terms of command-and-control centers, the headset is usually coded with practices of labor while the headphone is placed in the context of leisure. The headset 
thus stands as a reminder that the advertisements regarding headphones as promising a life of total relaxation and leisure are just that: advertisements. In other words, the older history of "headset" radio-DJs and telecommunication points to a larger "headset" culture of labor. As a result of the spread of cell phones, pagers and BlackBerries, the division of work and leisure, and as already mentioned, public and private, was becoming undone by a culture of mobile flexibility. This collapse was augmented by the media convergence of Walkman and cell phone in the figure of the multimedia handset (Goggin 2011: 63-73). Worries also proliferated regarding the inability to escape contact with others due to the omnipresence of cell phone culture (Goggin 2006: 36). This culture, based primarily on electric speech aimed at the prosaic life of work, is the material base of both headphone culture and DJ "club culture", which are primarily coded as leisure cultures aimed at the poetic life of electric music.

In the context of the headphone and headset, I employ the notion of the jetset in a triple sense. First, it is the supposed glamor of jetset disco travel and concert tours, exemplified in the present by the mass jetsets of EDM club tourism in 21st century Europe (Rapp 2009). Second, it is also the material base of labor, trade and transport that supports musical communication between regional scenes. Analyzed by Marc Dierikx, the economies of jetset travel rapidly expanded between the Cold War and the War on Terror:

1945: 8.2 million

1950: 27 million

1960: 106 million

1970: 301 million

1977: 517 million

1989: 1,119 million

2001: 1,640 million

2005: 2,022 million

-Air travel by passengers: figures provided by the International Civil Aviation Organization (Dierikx 2008: 145-9).

The glamor and labor, as well as danger, of jetset travel as necessary for the music industry has existed throughout this period. The dawn of the mass jetset age saw one of the most iconic tragedies in connection with the air travel of music stars, a tragic history to which Aaliyah's death contributed. On 3 February 1959, Buddy Holly, Ritchie Valens and the Big Bopper died in a plane crash, later made legendary in Don McLean's 1971 hit of nostalgic schmaltz, "American Pie". Nevertheless, five years later, the Beatles 1964 jetset tour would already stand as the pinnacle of the glamorous links of air travel and modern musical life (Dierikx 2008: 95-6).

Third, the jetset signifies the communications, acoustics and entertainment of the airplane and airport as sonic environments exemplary of the dialectics of sound in modernity. Friedrich Kittler emphasizes the role of pilots in transforming understandings of sound. In 
the "Gramophone" section of Gramophone, Film, Typewriter, Kittler writes: "Long before the headphone adventures of rock'n'roll or original radio plays, Heinkel and Messerschmitt pilots entered the new age of soundspace.... Historically, [the pilot] had become the first consumer of headphone stereophony that today controls us all" (1999: 100). The idea that headphones "isolate" listeners in a negative sense, as argued by Schafer and Bloom, does not move beyond the micro-examples of home stereos and mobile gadgets. Jetset mobility proves to be a macro-example of mobile media communications, represented in the literal form of the jumbo-jet and the 1970 introduction of the Boeing 747 amidst the rise of disco culture (Dierikx 2008: 76-8). This link is further exemplified by the audio firm Sennheiser, which has both lines of aviation and business headsets to complement its production of studio and DJ headphones.

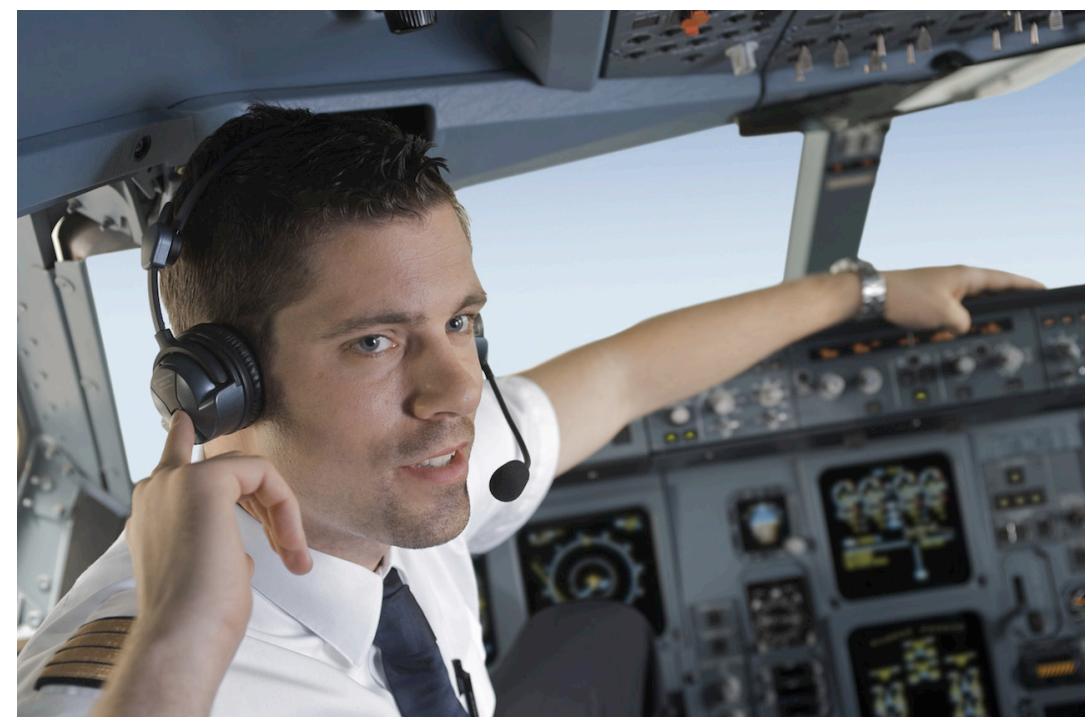

Figure 9: Pilot with Sennheiser HMEC-26 aviation headset. Image courtesy of Sennheiser.

It is likewise indicative that, while the Walkman was designed and marketed in 1978 and 1979, on 24 October 1978 the American Congress passed the Airline Deregulation Act, which ushered in a new era of tourism and market competition in air travel (Dierikx 2008: 121-2). Jetset music and sonic associations existed in EDM culture throughout, such as Jam \& Spoon's 1993 classic, "Follow Me" and Paul van Dyk's 2003 Global tour, important examples reflecting the jet engine flanging effects common to the trance genre.

Where pilots were concerned, headphones were also designed and refined with the aim to isolate sound in order to hear in loud environments. Moreover, headsets were developed in order to receive messages over long distances and, as opposed to telephones, to keep the hands free while traveling or working. Thus, before their close association with the Walkman culture of leisure, headphones operated within a longer history of headset aviation and labor. This history stretches from the original headsets of pilots in World War I biplanes, to 
the pilots described by Kittler, to the Plantronics of astronauts during the space race. The first open headphones, the Sennheiser HD 414 released in 1968, were likewise acquired by NASA for use in space flights while paving the way for the headphone design of the Walkman. Headphones, while offering a means to isolate hearing, are part and parcel of the most advanced technologies today that are "connecting the world". That headphones allow DJ listening to take place in similarly loud environments is an analogous practice.

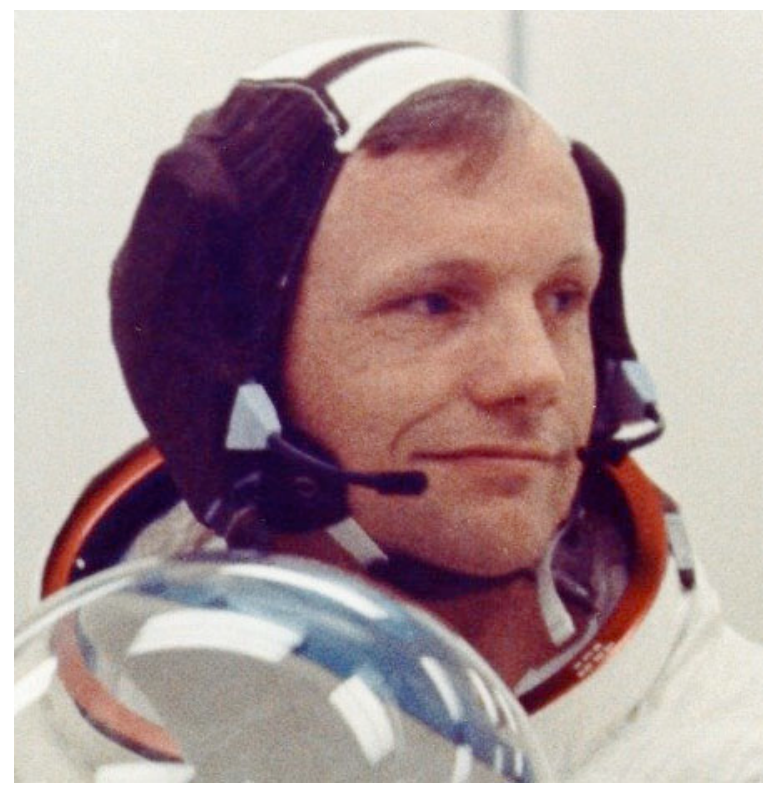

Figure 10. Neil Armstrong wearing Plantronics headset. Source: NASA images.

Placing Thornton's discussion of the postwar conquest of public space into the context of headset and jetset technologies, I am led back in time to the radically different associations that disc jockeys evoked in the context of the Cold War politics of the 1960s and early 1970s, during the inception of EDM disco culture. Questions of mobility are at this time augmented by images of ubiquity. Specifically, the Cold War link between headset communications and jetset pilots brings the DJ into the realm of a specific figure of the Cold War era: the cyborg. Since the coinage of the term cyborg in 1960, the rapid development of cyborg theory has focused on its consequences for anthropology in a global context. Originally coined by Manfred Clynes and Nathan Kline, the cyborg was the notion of the pilot carried to its extreme in the form of the astronaut. It referred to "the enhanced man who could survive in extraterrestrial environments" (Haraway 1995: xv).

The cyborg clearly emerged from the 1950 s military-industrial complex yet also presented utopian dreams of flight. In Donna Haraway's 1985 analysis, "A Cyborg Manifesto", a similar tension in the text, of which she is well aware, disturbs popular perceptions of her manifesto as a blankly technophilic celebration of the progressive potential of technology to undo gender binaries and national-imperial allegiances. The persistence of the dialectic of technology haunts her affirmation of the progressive potential of cyborgs. As she states: 


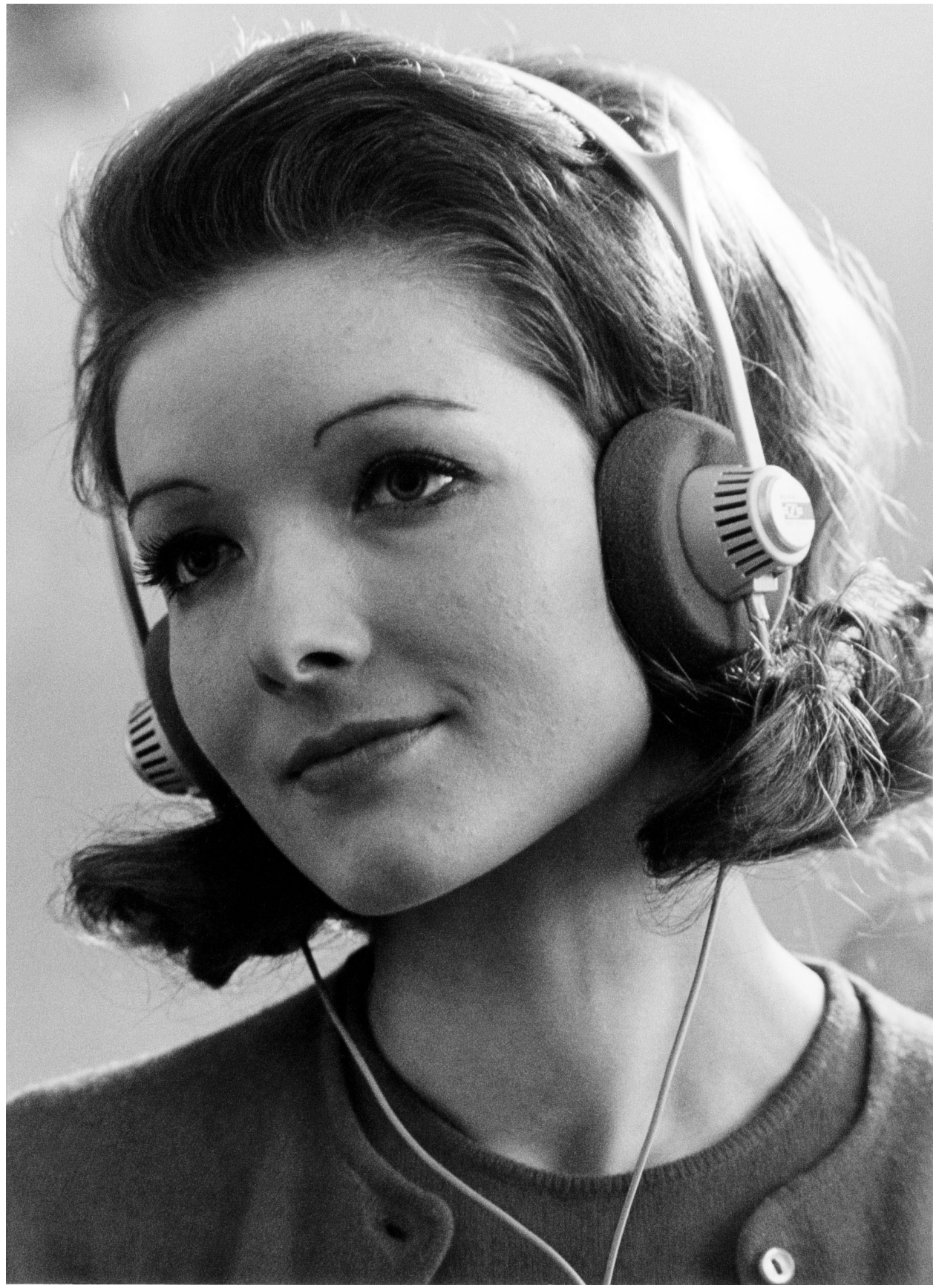

Figure 11. Woman with Sennheiser HD-414. Image courtesy of Sennheiser.

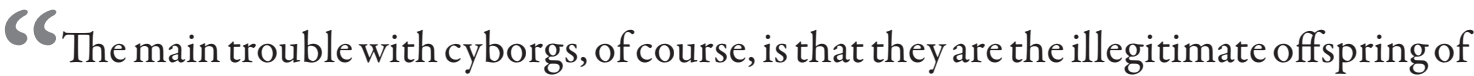
militarism and patriarchal capitalism, not to mention state socialism. But illegitimate offspring are often exceedingly unfaithful to their origins. Their fathers, after all, are inessential. -Donna Haraway (1991: 151) 
The disc jockey can be understood as an ambivalent figure similar to the pilot and the astronaut: disc jockeys are symbols of music mobility and communication across borders yet emerge from technologies of command-and-control that can be harnessed toward diverse ends, which both Kittler and Haraway clearly emphasize. To highlight this dialectic, I turn to a series of examples from California and West Germany, as two Cold War "Coasts" of techno culture and science fiction in which the figure of the disc jockey was explored with particular intensity. The examples, dating from 1965 to 1975, trace the disc jockey in the course of its transformation as representative of public broadcasting to club DJ.

In the context of the space race, a prescient work of literature that clearly saw the disc jockey in a cyborg context was the 1965 science fiction novel The Three Stigmata of Palmer Eldritch by Philip K. Dick. The disc jockey as commander of the radio airwaves demonstrates recorded music as a ubiquitous presence established through satellite communications. In part, the novel concerns the lives of colonists on Mars who survive by chewing the drug CAN-D while playing with plastic dolls called Perky Pat and toy objects. These objects are set in miniature worlds called "layouts" that remind the colonists of earth. The miniature worlds induce a 3-D experience of Earth when CAN-D is chewed. Both the dolls and the drugs are supplied by an international company called Perky Pat Layouts.

In order to advertise the latest editions for the layouts, the company has "disc jockeys", located in satellites that circle Mars. The disc jockeys operate as advertisers, beaming down the latest news regarding products to purchase in service of the hallucinatory trips. Dick thus blends plastic pop objects, radio communications and the "turn on, tune in, drop out" practices of West Coast counterculture in his imagining of a future world. Arguably, this absurdist future bears some comic resemblance to pop-plastic rave culture, illustrating rave as a late example in the long Cold War history of psychedelic countercultures since the 1950s.

This dialectic between headset and DJ culture on the West Coast is expanded a number of years later in the first two feature films by none other than George Lucas. THX-1138 (1971) envisions a future headset society, and, as a "nostalgia film" (Jameson 1991: 18-9), American Graffiti (1973) remembers an idealized radio DJ society of rock ' $\mathrm{n}$ ' roll and "cruising". The central importance of these films is demonstrated precisely by comparing them in terms of technological media; they anticipate Lucas's later iconic position as head of Skywalker Sound, a major innovator in the sound of blockbuster cinema. THX-1138 features headsets worn by managers in the command-and-control center, workers in the cyborg laboratory and pilots in jetcars. The original trailer features the shaved heads and signature Telefunken and Pioneer headphones that mark the headphone-skulls of the future society. The use of headsets considers the mediation as well as the total lack of private lives, in stark contrast to the 1980 s coding of headphones as private. When subjects open private medicine cabinets in their homes, there is always an answer from the command tower, viewing the subject through a hidden cam: "What's wrong?" Along with the jetcars, the context of jetset aviation is clear if one further considers that Lucas's award winning student film upon which THX-1138 is based, Electronic Labyrinth: THX-1138 4 EB (1967), was 
filmed primarily at Los Angeles International Airport and features a similar headset society.

This dystopia is set against the lost utopia of white teenagers in American Graffiti, who listen to the benevolent and liberatory electric speech of Wolfman Jack, the radio persona of Bob Smith, a famous "white negro disc jockey" of the 1950s (Brewster and Broughton 2000: 34). The original trailer is narrated in part by Wolfman Jack, and it features introductions of the various main characters, the final of which is DJ Wolfman Jack himself. In the film's disc jockey scene, the protagonist Curt Henderson meets Wolfman Jack at the radio station. Emphasizing occult media, the radio tower resembles a church steeple; the "religious" music of Sonny Till and the Orioles' "Crying in the Chapel" plays as Curt arrives. This music is followed by the song "A Thousand Miles Away" by the Heartbeats, which represents both Curt's longing for a distant love and the dispersed "body" of the radio DJ as omnipresent God. This founding presence in the radio DJ society is confirmed when Wolfman Jack insists: "The Wolfman is everywhere."

Like THX-1138, American Graffiti was anticipated in another student film by Lucas, The Emperor (1967). This short documentary concerns a Los Angeles radio DJ, Bob Hudson, who had a radio persona called The Emperor. The engagement with technology in this context of disc jockey and car culture is portrayed as positive and humanistic in American Graffiti, by comparison to the headset future of THX 1138. In short, here we have a clear demarcation between headset work and headphone-radio leisure. The mobility in American Graffiti is also the idealistic, social mobility of car cruising. To be sure, the film also ends with a "jetset" (though in a propeller plane, immediately prior to the rapid expansion of jet travel). Curt Henderson flies away from the idealistic Californian home, never to return. The film concludes with an announcement of the diverse fates of the four male characters, some of which are tragic and end the innocent era of teenage cruising.

The ubiquity of the radio DJ as understood by Dick and Lucas is later explored in an explicitly musical context on the other "Coast": namely in Kraftwerk's album Radio-Activity (1975). Interestingly, this album was initially inspired by a jetset itself, Kraftwerk's 1975 tour through the United States, which included many college radio interviews (Bussy 2001: 69). On the flight home, "suddenly, there was a theme in the air, the activities of radio stations" (Flür 2000: 77). Radio-Activity evolved as a concept album to the Cold War radio DJ, exploring radio's interaction with radioactivity and the history of bicoastal electronic/ recorded music.

The album consists of "radio music" that mixes the songs and the single "Radio-Activity" with tracks using radio samples or announcements. Three relatively short tracks appear in succession: "Sendepause" [Intermission]; "Nachrichten" [News]; "Die Stimme Der Energie" [The Voice of Energy]. The practice of radio disc jockeys in staking out territory is represented here in the more direct context of Cold War conflict than appears in American Graffiti. Hütter and Schneider listened extensively to the electronic music programs of Westdeutscher Rundfunk (WDR) in the 1950s and 1960s, listening which is subtly addressed in their engagement with the radio works by Werner Meyer-Eppler (Brocker 2011: 106). These programs were in part sponsored by the CIA and understood as propaganda to 
establish a specific postwar West German identity. The key roles also played by the military radio stations of both British and American Forces Networks and Munich-based Radio Free Europe (see Johnson 2008) in the reception of music and news in the two Germanies and Europe demonstrate the intertwining of the military-industrial complex and radio.

The Cold War context of atomic energy and radio transmission is expressed in the lyrics to the title track. It exploits the multiple meanings of "Radio-Activity" in German and English as well as in the third "language" of Morse code. The ubiquity of radio and radioactivity is plainly stated: "Radio-activity is in the air for you and me". The dialectic of occult media, technological media and questions of atomic apocalypse is expressed sonically. The choir drone produced by a Vako Orchestron synthesizer is a kind of synthetic-religious drone, an occult counterpart to the promethean potentials of technological media and atomic energy represented in the Geiger counter and distorted Morse code.

Among the radio announcement tracks, "Die Stimme Der Energie" gives a unique account of modern media, headsets and religious transcendence. "Die Stimme Der Energie" takes the form of a disc jockey announcement rather than a radio hit. It begins with rustling and distorted radio static and white noise, followed by the distinctly distorted baritone of the "Voice of Energy," a variation of a text by the phoneticist and vocoder acoustician Meyer-Eppler (Brocker 2011: 106). In this context, it is the voice of the radio DJ as RoboGod the Father. The immaterial ubiquity of the radio, combined with nuclear radioactivity, is transformed into an electronic deity. The German language is a mix of Lutheran Biblical allusions and Romantic-poetic genius, contrasting with the benevolent disc jockey Wolfman Jack of American Graffiti.

Hier spricht die Stimme der Energie Ich bin ein riesiger elektrischer Generator Ich liefere Ihnen Licht und Kraft Und ermögliche es Ihnen Sprache, Musik und Bild Durch den Äther auszusenden und zu empfangen

Ich bin Ihr Diener und Ihr Herr zugleich Deshalb hütet mich gut Mich, den Genius der Energie.

\section{Translation:}

This is the voice of energy I am a giant electric generator I supply you with light and power And make it possible to send and receive speech, music and image through the ether I am both your servant and master Therefore guard me well I, the genius of energy

Kraftwerk also explores the musical potential of radio and recorded music. One can observe this structure in "Radioland", a unique track that simultaneously represents both artistic creation and reception. Listener and producer collapse in this song of "recorded music". The track consists of Hütter and Schneider expressing in duet the various actions one performs on electronic instruments in the form of listening to shortwave radio. After each lyric, a corresponding sound indexes the act of sound creation. At the end, a final response is heard of a vocoder voice from "Radioland," somewhere between Disneyland and Deutschland. 
Telecommunications and radio are further exemplified in the track "Antenna", which delights in a techno-sensual "I-you" dialogue through radio: "I'm the antenna, catching vibration; you're the transmitter, give information!" "Antenna", along with tracks such as "Airwaves" and "Radio Stars", focuses on a headset mix of radio and the space age as index of NATO pop culture in the Cold War.

The disc jockey world of Radio-Activity can here be juxtaposed with Kraftwerk's 1981 album Computer World, which reveals a shift to the private and isolated associations of "headphone culture". Kraftwerk's theory of composition and collective reception in "Radioland" shifts to personalization and miniaturization in "Pocket Calculator". Composed in 1981, "Pocket Calculator" presents the musical practices of mobile media culture. The "we" of Radioland reception becomes the "I" of pocket calculator composition: "I'm the operator with my pocket calculator". The ongoing fetishization of miniaturization has made this track far more famous than the comparatively forgotten "Radioland", though it can be argued "Radioland" is just as important. Even before the official end of the Cold War, Computer World anticipates an age of neo-liberalism and globalization. There are no explicit references to Cold War themes.

Kraftwerk is undoubtedly a symbol of EDM DJ culture even though none of its members were DJs; rather, their concept albums and practices as sound technicians or "Operators" help to contextualize the DJ's relation to recorded music and sound studios. Indeed, it highlights the dialectical relation of EDM "headphone culture" between those of sound producers and DJs. In DJ culture, it is usually the double role of the DJ-producer that garners more attention than the solitary DJ. The attraction of DJ headphone performance is dependent upon the sound creations of music producers through studio headphones and the club sound systems. Headphones here recall the triple use of headphones I emphasized in the introduction: musical consumption, studio production and DJ performance.

To be sure, the production of electronic music has its own Promethean associations on a par with the omnipresence of the radio DJ or the performance of the club DJ. At the same moment that Philip K. Dick was imagining satellite disc jockeys on the other Coast, one of the great experimental films to deal with electronic music and technology was made: Mauricio Kagel's Antithese (1965). It concerns a solitary studio engineer who produces sound both by tape and by operating various instruments, including using gramophones like a DJ. $\mathrm{He}$ is experiencing the slow dissolving of his identity amidst the studio equipment. Though the male experimental scientist remains isolated, the technological devices ultimately relinquish him from the construction and domination of sound as private possession. He is manipulated by his instruments while he manipulates them. Like Kraftwerk in "Radioland", he listens as much as produces. At one point, he climbs atop a building and puts on headphones. He then throws down various headphones, televisions and radios for the passersby, yet this does not break his isolation. Antithese concludes in a schizophrenic episode in which his "double" is wrapped in magnetic tape and set out to sea.

This dialectic of Promethean technology and the dissolving of subjectivity raises issues of gender, race and politics of labor, also highlighted in Haraway's concept of the cyborg. 
Her manifesto rubs against the grain of anthropological and scientific "man" and deals with the consequences of cyborg technology for relations of race, gender and class. As she states, her concept is "a blasphemous anti-racist feminist figure" (Haraway 1995: xvi). Her modern cyborg figure, as applied to the DJ, runs against the grain of the primarily neo-primitive understandings of $\mathrm{DJ}$ roles that have been received in popular culture. These understandings are exemplified by Brewster and Broughton who describe the DJ as "the witchdoctor, the shaman, the priest" (2000: 4). Such categories of occult media need to be complicated by technological media as the historically grounded practice of late modernity.

Furthermore, Haraway's cyborg figure is constructed amidst 1980s mobile media but highlights the Cold War history explored in these sci-fi examples. It emphasizes the ambiguous stature of the DJ figure within market forces and class-gendered structures of technology. Unfortunately, the human with headphones and the popular silhouette of the cyborg head have primarily been the "man with headphones", often taking the form of the white male cyborg as pilot or astronaut. The long history of male DJs is also admitted by Brewster and Broughton: “Throughout this book the DJ is 'he' and this is not just a matter of grammatical simplicity. In DJing's 94 years, women have been largely frozen out of the picture, with precious exceptions" (2000: 377). ${ }^{10}$ The promise of DJ "facelessness" in the history of broadcasting was all too often undermined by other negative potentials of the DJ. As operator of technology, DJs became not only males but the single male on stage, operating as a kind of command-and-control figure over the audience: the boy with his toys. Thus, the club DJ is implicated in the male-dominated headset and jetset cultures traced in this larger history of technological media.

\section{DJs in Performance: Public and Private Headphones}

THIS DIGGING BACK IN TIME through media and mobility to the origins of postwar "headphone culture" helps to view the 2001 moment of DJ performances on stage with new eyes and ears. In this final section, I explore the precise significance of headphones to club DJ performance, the role of DJ listening as headset labor and finally the late history of the cyborg figure and the jetset in the 21 st century.

The historical sedimentation of club DJs as humans with headphones on stage can now be read within the specific context of the post-1960s dialectic of mobile listening as both individuation and conquest of public space. The constant shifting of headphone positions, as I observed in Detroit, marks the DJ as a specific form of listener. Unlike any other figure, the club DJ highlights the dialectical tension of public and private headphones through performance. The positions include placing the headphones on both ears, on one ear, or on neither ear, in which the headphones become a fetishized stereo necklace. The headphones mark that private listening is occurring on stage. However, this private listening is key to the suspense of the public performance. As the DJ constantly listens between monitors and headphones in order to prepare a track, the audience watches in suspense, because it does not know what new track will be played or sampled. It knows that listening is occurring, 
but not to what. It only knows that the new track has been carefully selected, whether for aesthetic or promotional reasons. Thus, the DJ's headphone listening primarily involves the establishing of a private listening space on stage, resulting in the mix's suspense.

A return to the notion of headset culture as the primary source of communication is helpful here. Like the dialogic mix that occurs between two turntables, the headphone listening of the $\mathrm{DJ}$ is opened out onto the crowd in a constant dialogue of musical telecommunication. The headphones in a club context want to become a headset that communicates through music. It is because the DJ is flirting with traditions of private listening that the crowd desires an intimate dialogue with the DJ. This explains the socio-aesthetic reasons behind the attraction of star DJs; the crowd recognizes its own practices of electric listening in the headphones of the DJ, while publicly celebrating the pleasures of stereophonic technology. In other words, the DJ headphone performance transmits the sonic potentials of studio headphone production and audiophile consumption.

This constant shift of headphone positions during the mix also signifies the practice of listening as labor. The headphones need to be moved swiftly and easily as the DJ performs multitask-hearing to various registers of sound: the headphones, the monitors, the sound system, the crowd noise, etc. The DJ understands the headphones not as an end in itself but as a tool. This is indicative of the fact that DJ culture is only partially related to the most dedicated audiophile communities within headphone culture. The use of headphones is always in the service of the mix. DJs select headphones on a functional basis: maneuverability, comfort and appropriate bass levels so that beat matching and other mixing practices can take place. The social role of DJs is thus in some respects contradictory. They are the main popular symbol of headphone listening on stage, but they are not primarily headphone listeners themselves.

Evidence for this can be found in the relative absence of DJs in the headphone and audiophile community, such as head-fi.org. Founded in June 2001, head-fi.org consists of over 100,000 members whose primary devotion is to the history, technology and quality control of headphones. It provides a forum for the industry and for listeners to test new equipment and provide "sound" advice. There is comparatively little DJ presence on this site, however, because for DJs, as stated, headphone listening is primarily dedicated to the mix. The main headphone issues of concern to DJs are their role in club performance and their ability to help preserve hearing. The specific design and marketing of DJ headphones came relatively late in history, starting in the late-1990s and popularized with the release of the Sony MDR-V700. Since then, DJ headphones have been continuously refined and expanded, including industry standards such as the Allen \& Heath Xone-XD-53 and the Sennheiser HD 25-1 II, worn by Speedy J and Chris Liebing respectively in the Native Instruments Traktor performance.

In terms of headphone labor, the "private" listening of club DJs causes suspicion. The audience often asks: what is the DJ actually doing? Labor can be performed in different ways. Some DJs make a paradoxically "scientific" performance, with few expressive gestures and total focus on the set. The success of the performance is demonstrated in "the music 


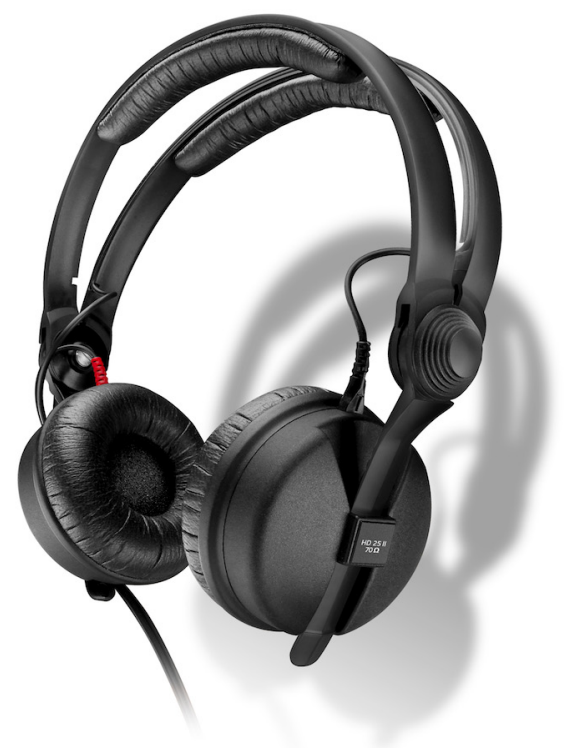

Figure 12: Sennheiser HD 25-1 Il. Winner of the DJmag Tech Awards for "Best Headphones", 2006-2009. IMAGE COURTESY OF SENNHEISER.

itself", which drives the crowd into frenzies that contrast with the DJ's private and focused space. In fact, the "scientific" posture of some DJs recalls the traditions of command-andcontrol in a number of respects. In the command of individual musical choice and skill, DJs keep calm and collected in the face of enormous expectations and stressful environments.

The antithesis of the scientific DJ performer is the one who gestures constantly, sometimes to the point of overcompensation, to prove to the audience that he or she is doing something. The DJ becomes a conductor: specifically, an electric conductor of crowd responses. Yet how the DJ presents the actions of the performance on stage becomes a challenge when compared with bands and traditional instruments. Though a fetish, the headphones as a gadget are more limited than, for example, the electric guitar in demonstrating one's star quality and music abilities. The electric guitar is quite obviously a phallic symbol with great stage presence, marking male prowess (Waksman 2001). Rather than the virtuosic performance of the guitar, the DJ's dancing and the subtle movements of the headphone focus on the pleasures of electric listening. The ear becomes the erogenous zone-as opposed to the lips of the singer or the hands and crotch of the guitarist. To be sure, kissing ears can be quite arousing.

At these moments, the DJ appears more open and queer than the rock guitarist, though as we have seen, the ideal of DJ-queerness has in some respects proven to be a feint. This is because, along with the vinyl, turntables and mixers, the headphones represent technology, which is supposed to be confined to the realm of man. Yet it remains the DJ, both club and radio DJ, who makes explicit the pleasures of electric listening in our time. In the moment 


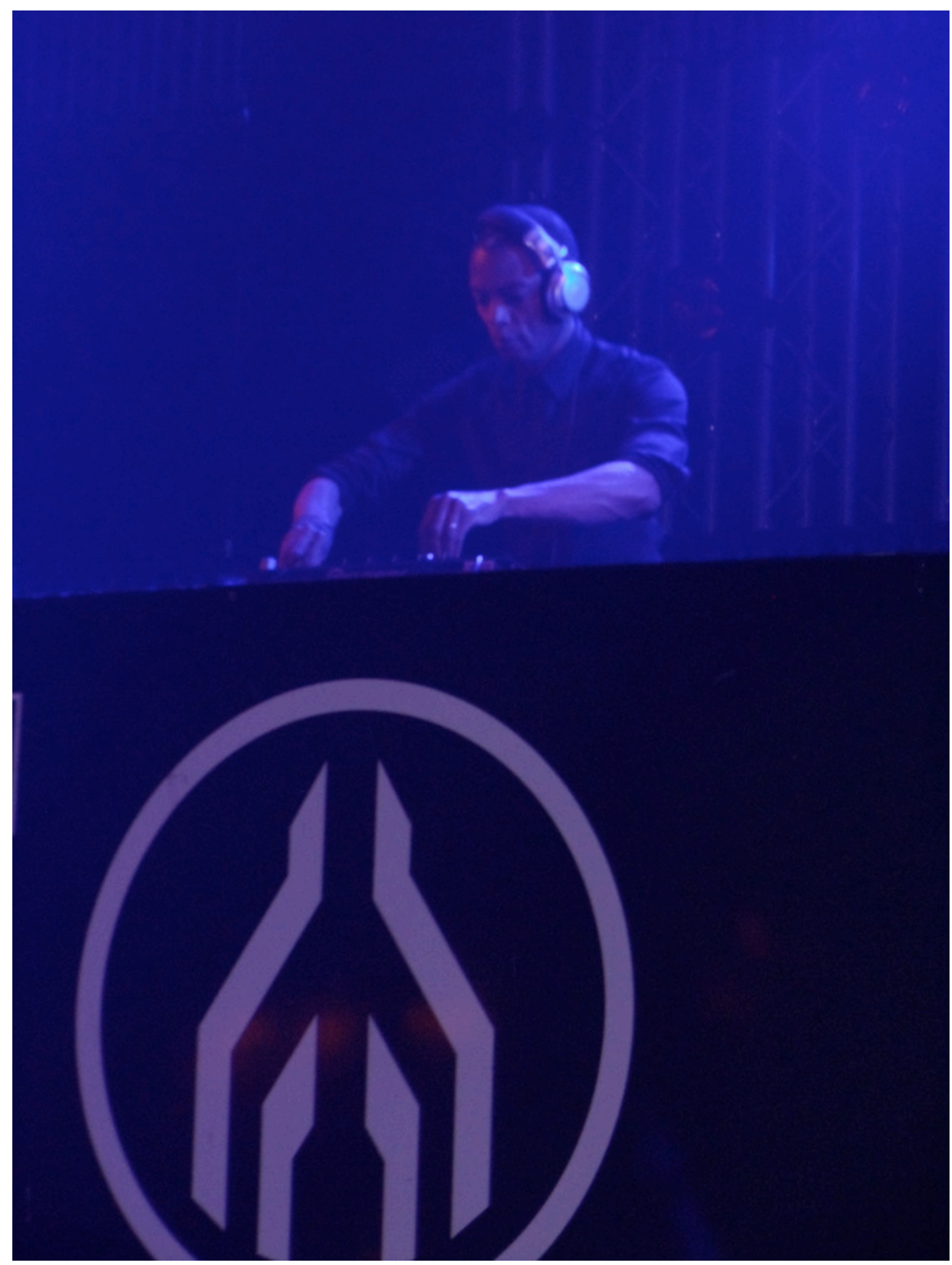

Figure 13. JefF Mills, Wearing SONy MDR-V7oo heAdphones, PERForming the MIX SCIENTIST, MAYDAY 2011. PHOTO by SEAN NyE. 
of performance, DJs are primarily the listeners who listen for us. The DJ functions as the expert of the "stockpiling of use-time" (Attali 1985: 124-32) ${ }^{11}$ that is the result of recorded sound collecting; in terms of labor time, the mix is prepared from many hours of listening at home, in the studio, in the club and on the streets. The headphones mark the central political-aesthetic role that listening plays within and through recording and phonography.

The fact that most DJs have been male might thus be used to recode popular understandings regarding listening and, in this context, electric listening. In the West, listening is usually thought of as a passive, vulnerable and even feminine practice. The existence of the DJ, whether male or not, places this non-sovereign notion of listening in doubt. Indeed, the very existence of the $\mathrm{DJ}$ is a threat to the traditional Western division between listening and performing, already explored by Kraftwerk in "Radioland" and Kagel in Antithese. Like the BlackBerries and cell phones that collapse public and private, home and work (Goggin 2006, 2011), the DJ collapses consumption and production.

Finally, the commitment to listening as labor, and at the extreme of loudness, marks the DJ as a suffering listener. The DJ's hearing in the context of the club suffers as much as the clubbers' if the proper ear protection is not employed. The desire for rapture at the limits of loudness leads to a suffering yet ecstatic listener and performer. Though the DJ during the last 30 years has symbolized the mastery of listening, such issues indicate the care of electric listening is still abused.

By way of conclusion, then, I turn to the question of listening at the limits of loudness. The great contribution of the "techno scene film" (Nye 2010) It's All Gone Pete Tong (2004) is that it puts listening at the forefront of the DJ's career. The film tells the story of the fictional Eurotrash DJ, Frankie Wilde, as the banal male chauvinist downfall of cyborg dreams. Originally from England, he has relocated to the commercial jetset clubs of Ibiza to establish his career. The headset economy of cheap tourism and the music business is represented by his manager, Max, whose cell phone earpiece is virtually a part of his body. Wilde's constant excess - the alcohol, drugs and the fortissimo sound systems of the Ibiza clubs-results in tinnitus. The film places the Beethoven myth of deafness (we hear the "Moonlight Sonata" as Wilde goes deaf) into the context of Eurotrash club culture. Deafness, however, is not an accident of illness but the consequence of excess and stupidity. Wilde must face deafness as symbolic of his abuse of the technological means to create a false stardom and a false society. It's All Gone Pete Tong shows the lack of care for electric listening's pleasures at maximum volume, where not even the culture of the deaf is understood. Frankie Wilde must come to terms with these limits and solve his challenges, though leaving the club and embracing his new life as a deaf man is his final redemption.

It's All Gone Pete Tong signifies the changed structures of labor and transport in the 2000s, which meant a subsequent banalization of jetset and cyborg figures in the popular mind. To an extent, the rise and fall of the DJ star has paralleled the rise and fall of jetset glamor. The jetset later turned into the "easyjetset" (Rapp 2009; Nye 2009) due to the rise of bargain airlines and the ubiquitousness of air travel today (Dierikx 2008): by 2005, the number of air passengers per year had already exceeded 2 billion. DJs are here recognized 
as laborers, suffering in an open economy of music downloading, file-sharing and ringtone culture (Goggin 2011: 55-79) and in a technoculture of rampant debt. At the moment that digital technology allowed beat-matching to go on auto-pilot, headset associations became increasingly transferred from pilots to less "glamorous" jobs as taxi drivers, office workers and fast-food servers. As has been indicated throughout this article, however, headset labor was always a part of this culture, placing the cyborg into everyday context. In terms of science fiction, it lands the space opera pilots in the cyberpunk problems of the dystopian present, which was highlighted in my encounter with the dystopian politics of Detroit techno (Pope 2011). Despite these grave problems, the current moment of the Technics 1200 discontinuation can hopefully also be seen as a moment for shifting attention towards an open future of new media technologies and practices while harnessing the revolutionary potential from past science fictions and sonic fictions (Eshun 1998). After all, the cyborg testing of volume and practice of phonography remain both the musical echoes and critiques of the headset pilots and astronauts, who broke the sound barrier and headed to outer space, all the while making sure the headphones were in their proper place so communication would not cease.

\section{ACKNOWLEDGEMENTS}

Many thanks to Elliott De Aratanha, Luis-Manuel Garcia, Sumanth Gopinath, Joshua Gunn, Mirko Hall, Graham St John and Erik Wijnands, as well as the guest editors and peer reviewers of this issue, for their advice and reviews of this article. Special thanks to Erik Wijnands for the headphone discussions and audiophile advice. Thanks to I-Motion and the crew of Mayday for their support and guidance, as well as to Sennheiser for the media support. And many thanks to Gabriel Rodriguez for the trip to Detroit.

\section{ENDNOTES}

1 For a thorough social and psychoanalytic theory of the gadget, see Gunn and Hall (2008), who consider gadgets as "devises fabricated expressly for stimulating various human desires or "drives" (2008: 136). In terms of technology, the gadget is a "tool or mechanism that is fetishized because of its novelty" (2008: 136). Gunn and Hall analyze the iPod as the primary gadget of the economy of earbud culture in the 2000s. The insertion of earbuds into the ear canals represents the achievement of the "sonorous envelope" (2008: 144-53), an experience of subjective absorption in music resulting in controversies associated with social and erotic issues. The teleology of headphone miniaturization and refinement, which I will explore later in the article, corresponds with this aim of the sonorous envelope.

2 "Headphones" and headphone culture are here understood under the general definition of an electroacoustic transducer for receiving sounds. The forms range from in-ear headphones (earbuds/in-ear-monitors) and on-ear headphones (earphones) to circumaural headphones (headphones with ear-encompassing pads). "Headphones" are often associated strictly with the last form. 
3 See, for example, discussions on head-fi.org.

4 Though electric listening is here metaphoric compared to Bell's invention of electric speech, it does emphasize the question of reception and listening discussed in Ronell's Telephone Book. Electronic music received through headphones emphasizes total electric mediation; music and medium reflect each other. For Ronell, though the telephone undermines the simple notion of "organ extension", she acknowledges: "Let us, for the sake of clarity, condense the telephone into a single supplementary organ, the mouth-ear" (1989: 104). If the telephone is the mouth-ear, two similarly condensed notions of supplementary organ might be considered: the double-ear of the headphones and the mouth-double-ear of the headset. In terms of media history, headphones are not "ear extensions" in the same way as devices such as hearing aids or earplugs. Yet, to the extent that they block out unwanted noise and enable "hearing" over long distances, they certainly represent a crucial form of "ear extensions". Electric listening thus registers the double anxiety of ear extensions: schizophonic and stereophonic.

5 Rickels offers an insightful analysis of German cultural theory regarding California as a "philosopheme" (1991: 6). In his comparative study, the "bicoastal" logic in the analysis of technological media and popular culture of the "Teen Age" is thoroughly explored.

6 One important example is the official refusal of DJ star Ricardo Villalobos to ever play in the United States while the Republicans were in power (Daily Swarm 2009).

7 See Sandoval (2010) and Technology Updates (2010). The Sony Walkman trademark continues in MP3 player formats. However, the Walkman name remains virtually synonymous with the portable cassette player version, whose 1979 introduction marked a revolution in mobile music. That the long production histories of the Technics 1200 and Walkman run in parallel and end in the same year is another indication of the dialectic of DJ culture and mobile media.

8 There are many gradations to this argument. For example, the volume can be up so loud that the sort of music one is listening to is audible to the other. The sheer loudness at once indicates indifference to the other and advertises one's private death drive to deafness. Just as some headphones contain sound poorly, so do shades of sunglasses allow for an interlocutor to see the eyes to varying degrees. For critics of modernity like Schafer and Bloom, the implicit threat of headphones was also the incursion of the other through the aggressive use of boom boxes in public places. In our current situation, the constant interference of personalized ringtones disturbs public places. This assertion and presentation of personal taste on the streets continually interrupts the private "isolated" worlds of others.

9 The sound mixer in the back versus the performers in front recall the allegory of Plato's cave; the audience is focused on the shining light on the stage of the performing musicians, though these are in fact prepared by the lighting and sound designers. The audience is faced away from them as in a psychoanalytic session.

10 The case of Broughton and Brewster is overstated, because their book neglects to examine significant female DJs, especially since the late 1980s. Some important examples would include Miss Djax, Marusha, Ellen Allien and Miss Kittin.

11 In 1977, Jacques Attali critiqued the recording industry and the stockpiling of use-time as the onset of the "repetitive society" (1985: 87-132) in what he saw as the total commodification of public space by the industrial products of recorded music. While the various practices of stockpiling offer an innovative analysis of late modernity, the poverty of Attali's critique lies perhaps in the failure to mention the subject of the DJ throughout this chapter. 


\section{REFERENCES}

Attali, Jacques. 1985 [1977]. Noise: The Political Economy of Music. Trans. Brian Massumi. Minneapolis: University of Minnesota Press.

Bloom, Allan. 1987. The Closing of the American Mind: How Higher Education Has Failed Democracy and Impoverished the Souls of Today's Students. New York: Simon and Schuster.

Brewster, Bill and Frank Broughton. 2000. Last Night a DJ Saved My Life: The History of the Disc Jockey. New York: Grove Press.

Brocker, Carsten. 2011. "Kraftwerk: Technology and Composition". Trans. Michael Patterson. In Kraftwerk: Music Non-Stop, ed. Sean Albiez and David Pattis, 97-118. London and New York: Continuum.

Bussy, Pascal. 2001 [1993]. Kraftwerk: Man, Machine and Music. London: SAF Publishing.

Cinquemani, Sal. 2001. "Aaliyah: Album Review”. Slant Magazine. 17 July: < http://www. slantmagazine.com/music/review/aaliyah-aaliyah/1> (accessed 11 May 2011).

Daily Swarm, The. 2009. "Ricardo Villalobos: Coming to America?" 15 February: <http://www. thedailyswarm.com/headlines/ricardo-villalobos-coming-america> (accessed 11 May 2011).

Dick, Philip K. 1991 [1965]. The Three Stigmata of Palmer Eldritch. New York: Vintage.

Dierikx, Marc. 2008. Clipping the Clouds: How Air Travel Changed the World. Westport, CN, and London: Praeger.

Ellis, Bret Easton. 2010 [1985]. Less Than Zero. London: Picador.

Eshun, Kodwo. 1998. More Brilliant Than the Sun: Adventures in Sonic Fiction. London: Quartet.

Goggin, Gerard. 2006. Cell Phone Culture: Mobile Technology in Everyday Life. London and New York: Routledge.

- - - 2011. Global Mobile Media. London and New York: Routledge.

Gunn, Joshua and Mirko M. Hall. 2008. "Stick it in Your Ear: The Psychodynamics of iPod Enjoyment”. Communication and Critical/Cultural Studies 5(2): 135-57.

Haraway, Donna. 1991 [1985]. "A Cyborg Manifesto: Science, Technology, and SocialistFeminism in the Late Twentieth Century". In Simians, Cyborgs, and Women: The Reinvention of Nature, 149-82. London: Free Association Books.

- _ . 1995. "Cyborgs and Symbionts: Living Together in the New World Order". In The Cyborg Handbook, ed. Chris Hables Gray, xi-xx. New York and London: Routledge.

Jameson, Fredric. 1991. Postmodernism Or The Cultural Logic of Late Capitalism. Durham, NC: Duke University Press.

Johnson, A. Ross. 2008. “A Brief History of RFE/RL”. Radio Free Europe/Radio Liberty. December: <http://www.rferl.org/section/history/133.html > (accessed 11 May 2011).

Keene, Darin. 2001. "Live: Life Fest". Chart Attack. 28 August: < http://www.chartattack.com/ node/46002> (accessed 11 May 2011).

Kittler, Friedrich. 1999 [1991]. Gramophone, Film, Typewriter. Trans. Geoffrey Winthrop-Young and Michael Wutz. Stanford: Stanford University Press.

Levy, Steven. 2006. The Perfect Thing: How iPod Shuffles Commerce, Culture, and Coolness. New York: Simon and Schuster.

Nye, Sean. 2009. Review of Lost and Sound: Berlin, Techno, und der Easyjetset. Dancecult: Journal 
of Electronic Dance Music Culture 1(1): 144-6. <http://dx.doi.org/10.12801/

1947-5403.2009.01.01.12> (accessed 15 May 2011).

- - 2010. "Review Essay: Run Lola Run and Berlin Calling". Dancecult: Journal of Electronic

Dance Music Culture 1(2): 121-7. <http://dx.doi.org/10.12801/1947-5403.2010.01.02.12>

(accessed 15 May 2011).

Pope, Richard. 2011. "Hooked on an Affect: Detroit Techno and Dystopian Digital Culture."

Dancecult: Journal of Electronic Dance Music Culture 2(1): 24-44.

<http://dx.doi.org/10.12801/1947-5403.2011.02.01.02> (accessed 15 May 2011)

Rapp, Tobias. 2009. Lost and Sound: Berlin, Techno und der Easyjetset. Frankfurt am Main: Suhrkamp.

Rickels, Laurence A. 1991. The Case of California. Minneapolis: University of Minnesota Press.

Ronell, Avital. 1989. The Telephone Book: Technology, Schizophrenia, Electric Speech. Lincoln, NE, and London: University of Nebraska Press.

Sandoval, Greg. 2010. "Goodbye Walkman, thanks for the iPod”. CNET.com. 25 October: <http://news.cnet.com/8301-13579 3-20020573-37.html> (accessed 15 May 2011)

Schafer, Murray R. 2004 [1973]. "The Music of the Environment”. In Audio Culture: Readings in Modern Music, ed. Christoph Cox and Daniel Warner, 29-39. New York: Continuum.

Sterne, Jonathan. 2003. The Audible Past: Cultural Origins of Sound Reproduction. Durham, NC: Duke University Press.

Technology Updates. 2010. "Sony Walkman Production Ends". 26 October: <http://www. technology-updates.com/sony-walkman-production-ends.html> (accessed 15 May 2011)

Tokyo Reporter. 2010. “Dead Spin: Panasonic Discontinues Technics Analog Turntables”. 28 October: <http://www.tokyoreporter.com/2010/10/28/dead-spin-panasonic-discontinuestechnics-analog-turntables/> (accessed 5 May 2011).

Waksman, Steve. 2001. Instruments of Desire: The Electric Guitar and the Shaping of Musical Experience. Cambridge, MA: Harvard University Press.

\section{DISCOGRAPHY}

Aaliyah. 2001. Aaliyah. Blackground Entertainment (CD): 724381008225. <http://www.discogs.com/Aaliyah-Aaliyah/master/35220>

Cybotron. 1984. Techno City. Fantasy (12-inch): D-226. <http://www.discogs.com/Cybotron-Techno-City/master/136 $>$

Jam \& Spoon feat. Plavka. 1993. "Right in the Night (Fall in Love with Music).” Epic (2x 12-inch): XPR 1993. <http://www.discogs.com/ Jam-Spoon-Right-In-The-Night-Fall-In-Love-With-Music-Follow-Me/release/297386>

Kraftwerk. 1975. Radio-Activity. Capitol Records (CD): ST-11457 <http://www.discogs.com/Kraftwerk-Radio-Activity/master/3228>

Kraftwerk. 1981. Computer World. Warner Bros. Records (CD): HS 3549. <http://www.discogs.com/Kraftwerk-Computer-World/master/3112>

Madonna. 1998. Ray of Light. Maverick (CD): 9 46847-2. <http://www.discogs.com/Madonna-Ray-Of-Light/master/67803 > 
Madonna. 2000. Music. Maverick (CD): 9 47598-2.

<http://www.discogs.com/Madonna-Music/master/34721>

van Dyk, Paul. 2003. Global. Mute (CD): 9201-2. <http://www.discogs.com/Paul-van-Dyk-Global/release/120026>

Various. 1973. American Graffiti: Original Soundtrack. MCA Records (Cassette): MCLDC 617. <http://www.discogs.com/Various-American-Graffiti-Original-Soundtrack/ release $/ 2590770>$

\section{FILMOGRAPHY}

“Apple Music Event 2001: The First Ever iPod Introduction." USA: Apple <http://www.youtube.com/watch?v=kN0SVBCJqLs > (accessed 24 May 2011)

Dowse, Michael. 2004. It's All Gone Pete Tong. UK: Lionsgate. <http://www.imdb.com/title/tt0388139/>

Isham, Wayne. 2000. Aaliyah feat. Timbaland: Try Again. USA: Hollywood Center Studios. <http://www.youtube.com/watch?v=nEF_-IcnQC4 > (accessed 15 May 2011)

Kagel, Mauricio. 1965. Antithese. Germany: < http://www.ubu.com/film/kagel_antithese.html> (accessed 24 May 2011)

Kosinski, Joseph. 2003. iSpec. USA: KDLAB. $<$ http://www.youtube.com/watch?v=aPQWFkvwFxE\&feature=related $>$ (accessed 24 May 2011)

- - 2010. Tron: Legacy. USA: Disney. <http://www.imdb.com/title/tt1104001/>

Liebing, Chris and Speedy J. 2009. "NI Traktor Pro Session.” Germany: Native Instruments. <http://www.youtube.com/watch?v=LHPLFPMintM> (accessed 24 May 2011)

Lucas, George. 1967a. The Emperor. USA: University of Southern California. <http://www.imdb.com/title/tt0061621/>

- - - 1967b. Electronic Labyrinth: THX 11384 EB. USA: University of Southern California. <http://www.imdb.com/title/tt0062331/>

- - 1971. THX 1138. USA: American Zoetrope. <http://www.imdb.com/title/tt0066434/>

- - - 1973. American Graffiti. USA: Universal Pictures. < http://www.imdb.com/title/tt0069704/>

Madonna. 2001. Drowned World Tour. USA: Warner Bros. <http://www.imdb.com/title/tt0294696/>

Reggio, Godfrey. 1983. Koyaanisqatsi. USA: Metro Goldwyn Mayer. <http://www.imdb.com/title/tt0085809/> 